\title{
Purin-6-One Derivatives as Phosphodiesterase-2 Inhibitors
}

\author{
Wei Yuan, ${ }^{1}$ Xin-Yun Zhao, ${ }^{1}$ Xi Chen, ${ }^{1}$ and Chang-Guo Zhan ${ }^{2}$ \\ ${ }^{1}$ College of Chemistry and Materials Science, South-Central University for Nationalities, Wuhan 430074, China \\ ${ }^{2}$ Department of Pharmaceutical Sciences, College of Pharmacy, University of Kentucky, 789 S. Limestone, Lexington, KY 40536, USA
}

Correspondence should be addressed to Xin-Yun Zhao; 45551525@qq.com and Xi Chen; ccnuchen@yahoo.com

Received 12 December 2015; Revised 14 January 2016; Accepted 17 January 2016

Academic Editor: José L. A. Mediano

Copyright (C) 2016 Wei Yuan et al. This is an open access article distributed under the Creative Commons Attribution License, which permits unrestricted use, distribution, and reproduction in any medium, provided the original work is properly cited.

\begin{abstract}
A series of purin-6-one derivatives were synthesized, and their in vitro inhibitory activity against phosphodiesterase-2 (PDE2) was evaluated by using a fluorescence polarization assay. Three compounds, that are, $\mathbf{2 j}, \mathbf{2} \mathbf{p}$, and $\mathbf{2 q}$, showed significant inhibitory activity against PDE2 with $\mathrm{IC}_{50}$ values of $1.73,0.18$, and $3.43 \mu \mathrm{M}$, respectively. Structure-activity relationship (SAR) analysis was performed to explore the relationship between the chemical structures of these compounds and their inhibitory activity. Compounds $2 \mathbf{j}$, $2 \mathbf{p}$, and $2 \mathbf{q}$ were further selected for molecular docking study. The docking results suggested that these ligands bind with hydrophobic pockets of the catalytic active site of PDE2, where a Tyr655 residue was found to be important in binding with compound 2p, the most potent inhibitor identified in this study. Our present study provides useful information for the future design of novel PDE2 inhibitors.
\end{abstract}

\section{Introduction}

Mammalian cyclic nucleotide phosphodiesterases (PDEs) could catalyze the hydrolysis of ubiquitous intracellular second messengers cyclic adenosine monophosphate (cAMP) and/or cyclic guanosine monophosphate (cGMP) into inactive $5^{\prime}$-AMP and/or $5^{\prime}$-GMP to modulate a number of physiological processes. Numerous studies have proved that PDEs were excellent drug targets for the development of therapeutic agents against various diseases $[1,2]$. The human genome encodes 11 PDE families (PDE1 to PDE11) to produce a series of PDE isoenzymes [3-5]. There is only one gene coding for PDE2, namely, PDE2A. PDE2A has been described to degrade both substrates cAMP and cGMP. Its enzymatic activity can be allosterically activated by cGMP. Additionally, PDE2A is preferentially expressed in the mammalian heart [6] and brain tissues [7]. Animal behavioral models have indicated that PDE2 inhibition plays a key role in the control of memory and anxiety [8-10]. It could also be considered as a promising therapeutic target for cognition enhancement in Alzheimer's disease [11].

Among the as-reported PDE2 selective inhibitors, there are four inhibitors particularly interesting to many scientists. As shown in Figure 1, EHNA was the first reported PDE2 inhibitor with $\mathrm{IC}_{50}$ value of $1 \mu \mathrm{M}$ [12]. BAY $60-7550$ and PDP (Figure 1) exhibited excellent inhibitory activities against PDE2A with $\mathrm{IC}_{50}$ values of 4.7 and $0.6 \mathrm{nM}$, respectively $[8,13]$. ND7001 was under development by Neuro $3 \mathrm{D}$ and advanced into clinical phase I in 2005, showing potent inhibitory activity against $\mathrm{PDE} 2[14]$ with $\mathrm{IC}_{50}$ value of $57 \mathrm{nM}$. However, according to the reports of Thomson Reuters Pharma, developments of BAY 60-7550 and ND7001 were ceased due to their poor pharmacokinetics performances [15].

Despite various X-ray crystal structures for PDE2 having been reported [16, 17], the shape of the binding pocket of PDE2 remained uncertain until 2013, when Huang et al. have reported the X-ray crystal structure of PDE2A complexed with BAY 60-7550 [18]. The crystal structure revealed that this compound binds to the PDE2 active site using not only the conserved glutamine-switch mechanism for substrate binding but also a binding induced hydrophobic pocket, which is lined by Leu770, His773, Thr805, Leu809, Ile866, and Ile870 (Figure 2). It has never been reported before. The binding mode of BAY 60-7550 with the active site of PDE2 in crystal state is depicted in Figure 2. As shown in this figure, the -NH-CO- moiety of BAY 60-7550 forms bidentate hydrogen bonding to the invariant glutamine (Gln859) and the imidazotriazin-4-one core stack against the side chain of Phe862 and Phe830. In addition, the phenyl ring is filled into 
<smiles>CCCCCC[C@@H](C(C)O)n1cnc2c(N)ncnc21</smiles><smiles>COc1ccc(Cc2nn3c([C@H](CCCc4ccccc4)C(C)O)nc(C)c3c(=O)[nH]2)cc1OC</smiles>

BAY 60-7550<smiles>COc1ccc(Cc2nc3c(ncn3C(CCCc3ccccc3)C(C)=O)c(=O)[nH]2)cc1OC</smiles>

Figure 1: Structures of EHNA, BAY 60-7550, PDP, and ND7001.

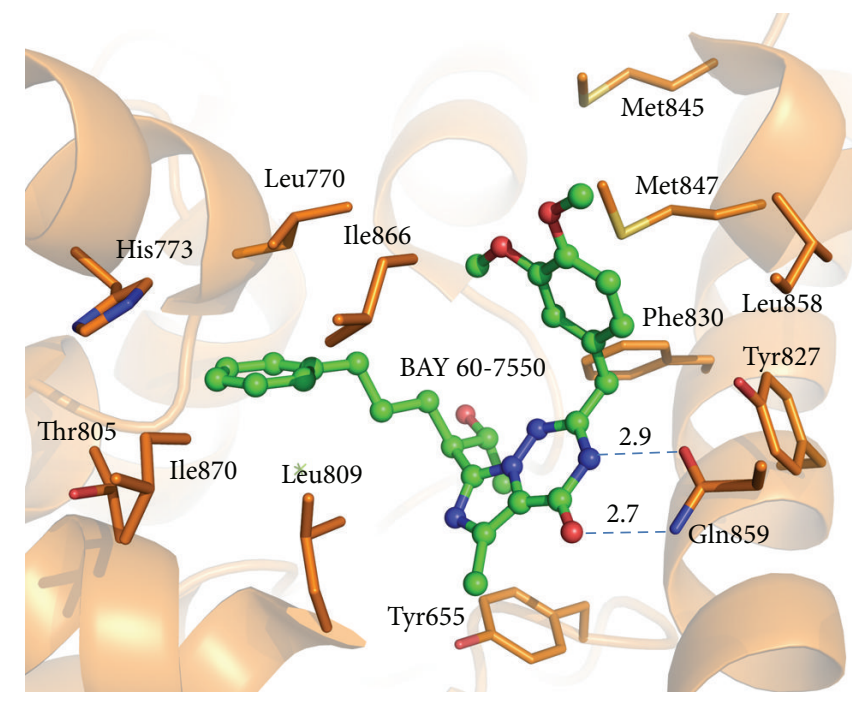

FIgURE 2: The interaction of BAY 60-7550 with the catalytic domain of PDE2 (PDB ID: 4HTX). The BAY compound is rendered with green color scheme. Residues that form key interactions with BAY compound are rendered with orange color scheme. The environmental protein surrounding is rendered in orange. For the convenience of display, some residues are not shown.

the binding induced hydrophobic pocket, which significantly contributes to the binding of BAY 60-7550 with PDE2.

Inspired by the information mentioned in Figure 2, a series of purin-6-one derivatives were designed and synthesized by keeping the core scaffolds purin-6-one and changing the substituents at 2- and 9-positions on the purin-6-one. Fluorescence polarization assay was performed to test the inhibitory effect in vitro using recombinant human PDE2 in the presence of $10 \mu \mathrm{M}$ of inhibitors. For those compounds with higher inhibitory activity, $\mathrm{IC}_{50}$ values against PDE2 were also determined. Ligand-protein docking studies were performed to investigate the binding modes of these purin-6one derivatives with the PDE2 catalytic domain. Our present studies provide useful information for the design of novel PDE2 inhibitors.

\section{Results and Discussion}

2.1. Chemistry. All compounds synthesized in this study have been summarized in Table 1. The general synthetic routes of these target compounds are depicted in Scheme 1. The key intermediates 5-amino-1-substituted-imidazole-4carboxamides $\mathbf{1}(\mathbf{1 a}, \mathbf{1 c}, \mathbf{1 d}, \mathbf{l i}, \mathbf{1 n}$, and $\mathbf{1 p}$ ) were firstly synthesized (Scheme 1) using amines, 2-amino-2-cyanoacetamide, and triethyl orthoformate as raw materials. Their synthetic route was modified from the work of Banerjee et al. [19] by adding pyridine as catalyst under the refluxing conditions. The yield of $1 \mathbf{a}\left(\mathrm{R}=\mathrm{CH}_{2} \mathrm{CH}_{2} \mathrm{OH}\right)$ was higher $(73.2 \%)$ than that reported (42\%) in the work of Banerjee et al. The melting point and ${ }^{1} \mathrm{H}$ NMR of $\mathbf{l c}\left(\mathrm{R}=\mathrm{CH}_{2} \mathrm{C}_{6} \mathrm{H}_{5}\right)$ were found to be consistent with those reported by Shaw and Alhede [20, 21]. Compounds $\mathbf{l n}$ and $\mathbf{l p}$ were synthesized by using 3 -amino4-phenyl-butan-2-ol and 3-amino-6-phenyl-hexan-2-ol as starting materials. Target compounds were synthesized by refluxing intermediates 1 and the corresponding esters in the presence of sodium methoxide. Purin-6-one derivative $2 \mathrm{c}$ was then reacted with allyl bromide to give N1-alkylated $(2 \mathrm{c}-1)$ and O6-alkylated $(2 \mathrm{c}-2)$ products in the presence of $\mathrm{NaH}$. Compounds $\mathbf{2 n}$ and $2 \mathbf{o}$ were further oxidized to $\mathbf{2 r}$ and $2 \mathrm{~s}$ under DMSO using $\mathrm{SO}_{3}$ /pyridine complex [22]. Their structures were confirmed by ${ }^{1} \mathrm{H}$ NMR, ${ }^{13} \mathrm{C}$ NMR, IR, and mass spectroscopy. The single-crystal structure of compound 2a was also determined by our X-ray crystallography [23].

2.2. Inhibitory Activity of Purin-6-One Derivatives against PDE2 and SAR Studies. The in vitro inhibitory activity against the recombinant human PDE2 was evaluated for final compounds by using fluorescence polarization assay. The inhibition ratios of target compounds against PDE2 in the presence of $10 \mu \mathrm{M}$ of inhibitor were summarized in Table 1 . Results from Table 1 indicated that varying substituent at the 2- and 9-position will lead to remarkably different inhibitory activities. Keeping $\mathrm{R}=-\mathrm{CH}_{2} \mathrm{CH}_{2} \mathrm{OH}$, replacing $\mathrm{R}^{1}$ (3methoxybenzyl) in compound 2 a with 3,4-dimethoxybenzyl (compound 2b) will increase inhibitory ratio from $48 \%$ (2a) to $78 \%(\mathbf{2 b})$. When $\mathrm{R}$ and $\mathrm{R}^{1}$ were, respectively, to be $-\mathrm{CH}_{2} \mathrm{C}_{6} \mathrm{H}_{5}$ and 2-methylbenzyl (compound 2c), the inhibitory ratio value decreased to $35 \%$. It was postulated that large nonpolar groups at $\mathrm{R}$ substituent will be unfavorable for PDE2A inhibition. This assumption is further confirmed by the inhibitory values (18-42\%) of compounds $\mathbf{2} \mathbf{d}$ and $\mathbf{2 f}-\mathbf{2 h}$, $\mathrm{R}$ groups of which were nonpolar group $-\left(\mathrm{CH}_{2}\right)_{3} \mathrm{C}_{6} \mathrm{H}_{5}$. The only exception is compound $2 \mathrm{e}$; the inhibitory ratio is $78 \%$, which is the same as the inhibitory value of $\mathbf{2} \mathbf{b}$. Increasing the chain length of $\mathrm{R}$ in compound $2 \mathrm{e}$ to $-\left(\mathrm{CH}_{2}\right)_{4} \mathrm{C}_{6} \mathrm{H}_{5}$ leads to compound $\mathbf{2} \mathbf{i}$, which has an inhibitory activity essentially identical to that of 2e. Further adding a methoxyl group to 3-position of phenyl ring of $R^{1}$ in $2 \mathbf{i}$ results in compound $2 \mathbf{j}$, which has a significant stronger inhibitory activity with a value of $95 \%$. In contrast, adding a methyl group to 
TABLE 1: Molecular structures and PDE2 inhibitory activity of purin-6-one derivatives (see Scheme 1, compounds 2a-2q).

\begin{tabular}{|c|c|c|c|}
\hline Compound & $\mathrm{R}$ & $\mathrm{R}^{1}$ & \% Inhibition (at $10 \mu \mathrm{M}$ inhibitor) \\
\hline $2 a$ & $-\mathrm{CH}_{2} \mathrm{CH}_{2} \mathrm{OH}$ & 3-Methoxybenzyl & 48 \\
\hline $2 b$ & $-\mathrm{CH}_{2} \mathrm{CH}_{2} \mathrm{OH}$ & 3,4-Dimethoxybenzyl & 78 \\
\hline $2 c$ & $-\mathrm{CH}_{2} \mathrm{C}_{6} \mathrm{H}_{5}$ & 2-Methylbenzyl & 35 \\
\hline $2 d$ & $-\left(\mathrm{CH}_{2}\right)_{3} \mathrm{C}_{6} \mathrm{H}_{5}$ & 3,4-Dimethoxyphenyl & 44 \\
\hline $2 \mathrm{e}$ & $-\left(\mathrm{CH}_{2}\right)_{3} \mathrm{C}_{6} \mathrm{H}_{5}$ & Benzyl & 78 \\
\hline $2 \mathrm{f}$ & $-\left(\mathrm{CH}_{2}\right)_{3} \mathrm{C}_{6} \mathrm{H}_{5}$ & 2-Methylbenzyl & 35 \\
\hline $2 \mathrm{~g}$ & $-\left(\mathrm{CH}_{2}\right)_{3} \mathrm{C}_{6} \mathrm{H}_{5}$ & 4-Chlorophenyl & 18 \\
\hline $2 \mathrm{~h}$ & $-\left(\mathrm{CH}_{2}\right)_{3} \mathrm{C}_{6} \mathrm{H}_{5}$ & 2,4-Dichlorophenoxyethyl & 42 \\
\hline $2 \mathbf{i}$ & $-\left(\mathrm{CH}_{2}\right)_{4} \mathrm{C}_{6} \mathrm{H}_{5}$ & Benzyl & 78 \\
\hline $2 \mathbf{j}$ & $-\left(\mathrm{CH}_{2}\right)_{4} \mathrm{C}_{6} \mathrm{H}_{5}$ & 3-Methoxybenzyl & $95\left(1731^{\mathrm{a}}\right)$ \\
\hline $2 \mathrm{k}$ & $-\left(\mathrm{CH}_{2}\right)_{4} \mathrm{C}_{6} \mathrm{H}_{5}$ & 2-Methylbenzyl & 24 \\
\hline 21 & $-\left(\mathrm{CH}_{2}\right)_{4} \mathrm{C}_{6} \mathrm{H}_{5}$ & 2,4-Dichlorophenoxyethyl & 34 \\
\hline $2 \mathrm{~m}$ & $-\left(\mathrm{CH}_{2}\right)_{4} \mathrm{C}_{6} \mathrm{H}_{5}$ & 4-Chlorophenyl & 30 \\
\hline $2 n$ & $-\left(\mathrm{CH}_{3} \mathrm{CHOH}\right) \mathrm{CHCH}_{2} \mathrm{C}_{6} \mathrm{H}_{5}$ & Benzyl & 73 \\
\hline 20 & $-\left(\mathrm{CH}_{3} \mathrm{CHOH}\right) \mathrm{CHCH}_{2} \mathrm{C}_{6} \mathrm{H}_{5}$ & 2-Methylbenzyl & 70 \\
\hline $2 p$ & $-\left(\mathrm{CH}_{3} \mathrm{CHOH}\right) \mathrm{CH}\left(\mathrm{CH}_{2}\right)_{3} \mathrm{C}_{6} \mathrm{H}_{5}$ & Benzyl & $100\left(184^{\mathrm{a}}\right)$ \\
\hline $2 q$ & $-\left(\mathrm{CH}_{3} \mathrm{CHOH}\right) \mathrm{CH}\left(\mathrm{CH}_{2}\right)_{3} \mathrm{C}_{6} \mathrm{H}_{5}$ & 4-Chlorophenyl & $99\left(3427^{\mathrm{a}}\right)$ \\
\hline $2 \mathbf{r}$ & $-\left(\mathrm{CH}_{3} \mathrm{CO}\right) \mathrm{CHCH}_{2} \mathrm{C}_{6} \mathrm{H}_{5}$ & Benzyl & 75 \\
\hline $2 s$ & $-\left(\mathrm{CH}_{3} \mathrm{CO}\right) \mathrm{CHCH}_{2} \mathrm{C}_{6} \mathrm{H}_{5}$ & 2-Methylbenzyl & 78 \\
\hline $2 c-1$ & \multicolumn{2}{|c|}{ 1-Allyl-9-benzyl-2-(2-methyl-benzyl)-1,9-dihydro-purin-6-one } & 56 \\
\hline $2 c-2$ & \multicolumn{2}{|c|}{ 6-Allyloxy-9-benzyl-2-(2-methyl-benzyl)-9H-purine } & 9 \\
\hline
\end{tabular}

${ }^{\mathrm{a}} \mathrm{IC}_{50}(\mathrm{nM})$.

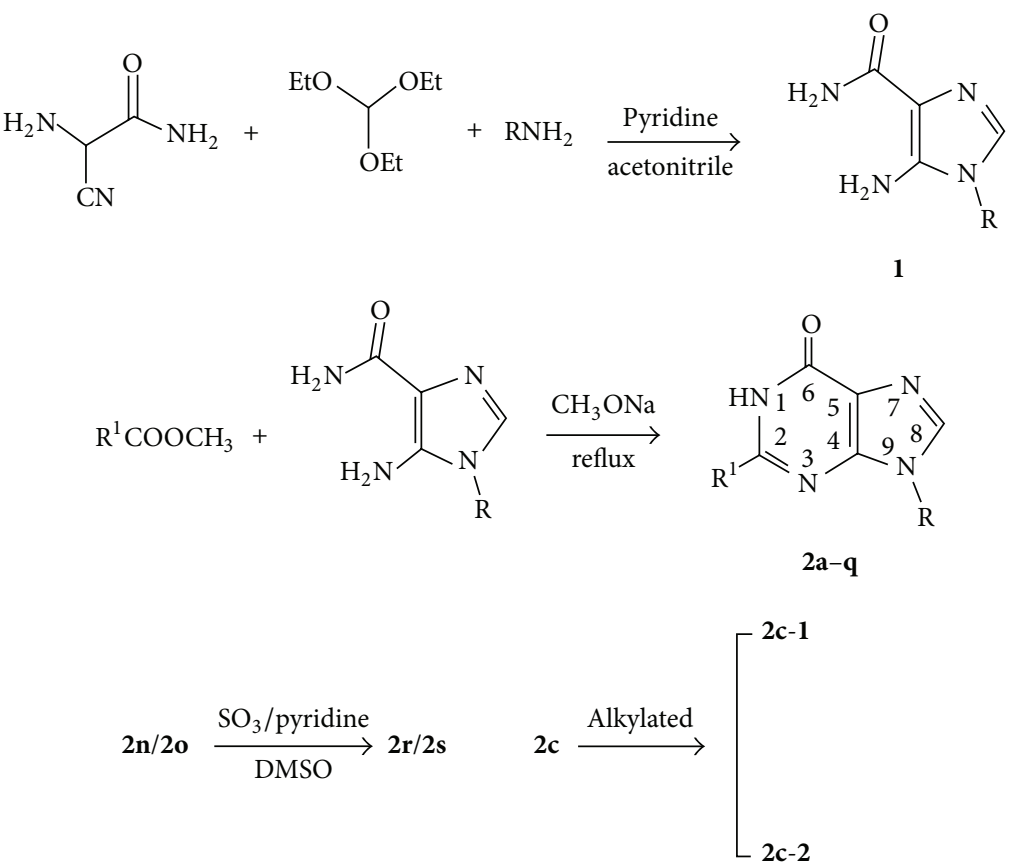

SCHEME 1: Synthesis of purin-6-one derivatives.

the 2-position of phenyl ring of $\mathrm{R}^{1}$ in $\mathbf{2 i}$ (compound $\mathbf{2 k}$ ) leads to a much less potent inhibitory with a value of only $24 \%$. The difference of $\mathrm{R}^{1}$ groups and inhibitory values between $\mathbf{2} \mathbf{j}$ and $2 \mathbf{k}$ clearly demonstrates that adding a moderately nonpolar group at the 3 - or 5-position of benzyl at $\mathrm{R}^{1}$-position is favorable.
Based on the discussion above, we further compare the structure of $\mathbf{2 b}$ and $\mathbf{2 d}$. It could be found that the presence of a hydroxyl (e.g., $-\mathrm{CH}_{2} \mathrm{CH}_{2} \mathrm{OH}$ ) in $\mathrm{R}$ group is more favorable than a nonpolar $\mathrm{R}$ substituent (e.g., $\left.-\left(\mathrm{CH}_{2}\right)_{3} \mathrm{C}_{6} \mathrm{H}_{5}\right)$ without a hydroxyl. In addition, comparing the inhibition ratio of $\mathbf{2 d}(44 \%)$ to that of $\mathbf{2} \mathbf{j}(95 \%)$, one can find that 
the bulkiness of $\mathrm{R}$ group should also be important to the PDE2A inhibition. Combining these two points, we tried to introduce a bulky $-\left(\mathrm{CH}_{3}\right) \mathrm{CH}(\mathrm{OH})$ group to the existing $\mathrm{R}$ group of $\mathbf{2 i}$. The resulting compound, that is, $\mathbf{2} \mathbf{p}$, shows excellent inhibitory activities with inhibition ratio of $100 \%$. However, when the $-\left(\mathrm{CH}_{3} \mathrm{CHOH}\right) \mathrm{CH}\left(\mathrm{CH}_{2}\right)_{3} \mathrm{C}_{6} \mathrm{H}_{5}$ group of compound $2 \mathbf{p}$ was replaced with a less bulky group, that is, $-\left(\mathrm{CH}_{3} \mathrm{CHOH}\right) \mathrm{CHCH}_{2} \mathrm{C}_{6} \mathrm{H}_{5}$ (compound 2n), the corresponding inhibition ratio drops to $73 \%$. Hence, the presence of hydroxyl and bulky size of $\mathrm{R}$ group are both important for inhibition activity.

Beltman et al. have reported a series of cGMP analogues and evaluated the inhibitory activities of these compounds against PDE2. The N1-methylated cGMP analogues generally exhibited weak inhibitory activity, as compared to those cGMP analogues with a hydrogen on N1. SAR study suggested that N1-methylation of cGMP analogues will result in the loss of a hydrogen bond or increase the steric hindrance with the binding pocket of PDE2, which will lead to reduced inhibitory activities [24]. This study concerns the importance of maintaining bidentate hydrogen bonds formed between the $\gamma$-amide of Gln859 and the carbonyl O6, NH moiety of the inhibitors. To testify this idea, we also synthesized N1-allylated derivative of compound 2c, namely, 2c-1. Interestingly, we observed a remarkably improved inhibitory activity of compound 2c-1 (N1-allylation), which is contrary to Beltman's reports. As can be seen from Table 1, the inhibitory ratio of $\mathbf{2 c - 1}$ is higher (57\%) than that (35\%) of 2c. Although 2c-1 loses a hydrogen donor at its N1position because of the allylation at this place, the loss of the hydrogen bonding interaction can be compensated by the hydrophobic interaction formed between the allyl group and the surrounding hydrophobic pocket of PDE2. Hence, for purine-6-one derivatives it is not necessary to form a bidentate hydrogen bond between the $\mathrm{N} 1-\mathrm{H}$ and $\gamma$-amide of Gln859 to maintain optimal PDE2 inhibitory activity. On the other hand, when the O6-position of $2 \mathrm{c}$ is attached with an allyl group, the resulting compound $\mathbf{2 c - 2}$ shows a much weaker inhibitory activity (9\%), as compared to that (35\%) for 2c. Our present study shows that the carbonyl oxygen at 6-position of purin-6-one scaffold (the scaffold consists of atoms 1 to 9. See Table 1 for numbering of these atoms) probably plays a key role in binding with PDE2.

The values in Table 1 show that compounds $2 \mathbf{j}, 2 \mathbf{p}$, and 2q have potent inhibitory activities. These three compounds were then selected for further inhibitory activity tests at various concentrations in order to calculate $\mathrm{IC}_{50}$ value, which showed a submicromolar inhibitory activity.

2.3. Molecular Modeling. The results from the preliminary activities prompted us to pay attention to three of the more potent compounds $(\mathbf{2} \mathbf{j}, \mathbf{2} \mathbf{p}$, and $\mathbf{2 q})$ with higher inhibitory activity against PDE2. In an effort to gain an understanding of the structural basis for the empirical structure-activity relationships observed, we further studied the binding mode of the compounds $(\mathbf{2} \mathbf{j}, \mathbf{2} \mathbf{p}$, and $\mathbf{2 q})$ through molecular docking. For this purpose, the crystal structure of PDE2 in complex with BAY 60-7550 (PDB ID: 4HTX) was selected as the receptor for molecular docking. Before docking,
TABLE 2: Calculated binding free energies in comparison with available experimental data (all in $\mathrm{kcal} / \mathrm{mol}$ ).

\begin{tabular}{lccc}
\hline Compound & $\Delta \mathrm{G}_{\text {bind }}$ cal $^{(\mathrm{a})}$ & $\mathrm{IC}_{50}(\mu \mathrm{M})$ & $\Delta \mathrm{G}_{\text {bind }} \exp (\mathrm{b})$ \\
\hline $\mathbf{2} \mathbf{j}$ & -9.11 & 1.731 & -7.8 \\
$\mathbf{2} \mathbf{p}$ & -9.80 & 0.184 & -9.2 \\
$\mathbf{2 q}$ & -8.85 & 3.427 & -7.4 \\
\hline${ }^{(\mathrm{a})}$ Binding free energies predicted by AUTODOCK. & \\
${ }^{(\mathrm{b})}$ Binding free energies derived from the experimental $\mathrm{IC}_{50}$ values.
\end{tabular}

the complex-ligand and water molecules were removed from the complex structure, except for four water molecules and a hydroxide ion that bound with the metal ions $\mathrm{Zn}^{2+}$ and $\mathrm{Mg}^{2+}$ at the catalytic pocket. Then hydrogen atoms were added by using the Leap tools implemented in AMBER software. The molecular structures of $\mathbf{2 j}, \mathbf{2 p}$, and $\mathbf{2 q}$ were constructed by GaussView followed by geometrical optimization at PM3 level. For the receptor and each ligand, the nonpolar hydrogen atoms were merged and Gasteiger charges were added. Then AUTODOCK4.2 program was used to search for the most favorable binding mode of the ligands and PDE2 catalytic domain. During the docking process, atoms in the receptor were kept constant. 100 docking runs were performed for each ligand and the conformations with the lowest binding free energies were selected for analysis.

Molecular docking revealed that all of these inhibitors bind with PDE2 in a similar binding mode (Figure 3). From this figure, it could be found that each of the PDE2 inhibitors was fitted in a cavity formed by Phe830, Phe862, Ile826, Gln859, Met845, Met847, Leu770, His773, Leu809, Ile866, and Ile870 residues. In the PDE2-ligand binding complexes (Figure 3), the common purin-6-one scaffold of the inhibitors is lodged in the hydrophobic pocket surrounded by the side chains of Ile826, Ile866, Phe830, and Phe862 residues, causing a high degree of surface complementarities. Hydrogen bonds were formed between the purin-6-one and the $\gamma$-amide of Gln859. In addition, $\mathrm{R}$ groups of ligands were clapped by the hydrophobic H pocket formed by His773, Leu809, Ile866, and Ile870 residues, which was also observed in the crystal structure of PDE2 in complex with BAY 60-7550. $\mathrm{R}^{1}$ group of the inhibitors formed additional hydrophobic interaction with the peripheral residues Met847, Leu858, and Ile866.

In addition to the common features mentioned above, the hydroxyl group of $\mathrm{R}^{1}$ substituent of inhibitor $\mathbf{2 p}$ forms an extra hydrogen bonding interaction with the side chain of Tyr655 (see Figure 3(b)), which will enhance the binding of $2 \mathbf{p}$ with PDE2. Compared to the binding mode of $\mathbf{2 p}$, 2j (Figure 2(a)) and 2q (Figure 2(c)) do not interact with Tyr655, implying that their binding affinities with PDE2 will be weaker than that of $2 \mathbf{p}$. As can be seen from Table 2, the binding free energies $\left(\Delta \mathrm{G}_{\text {bind }}{ }^{\mathrm{cal}}\right)$ predicted by AUTODOCK are consistent with the corresponding experimental binding free energies $\left(\Delta \mathrm{G}_{\mathrm{bind}}{ }^{\exp }\right)$, suggesting that the present binding modes of these compounds are reliable.

It is worth noting that the interaction with Tyr655 has never been reported before. Hence, this residue can be considered as a new site for the development of novel PDE2 


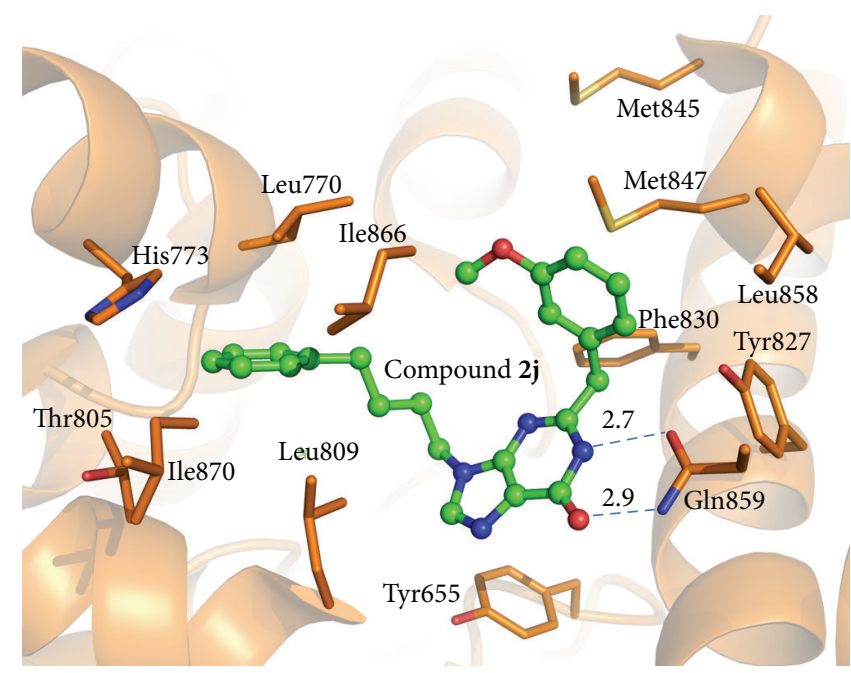

(a)

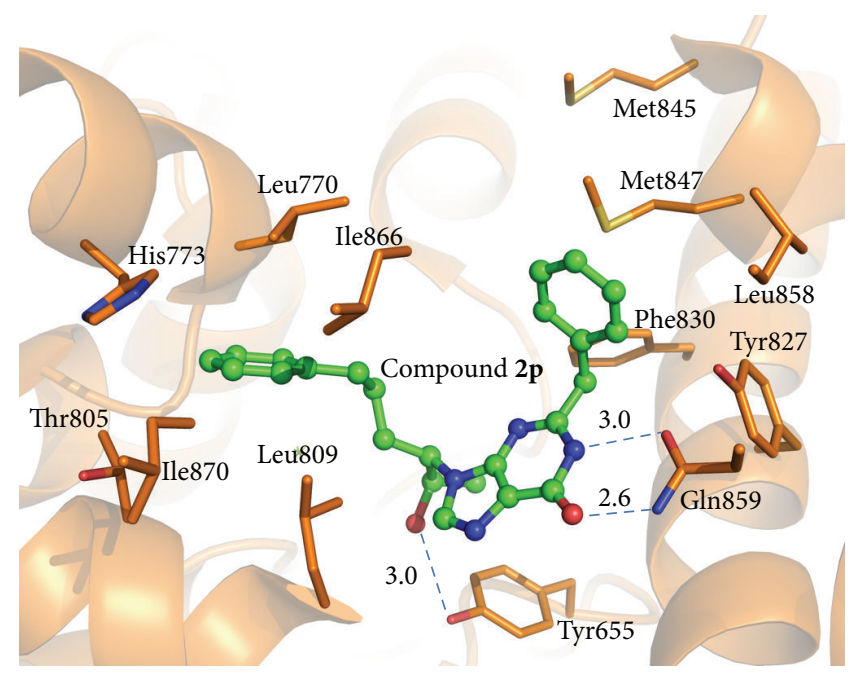

(b)

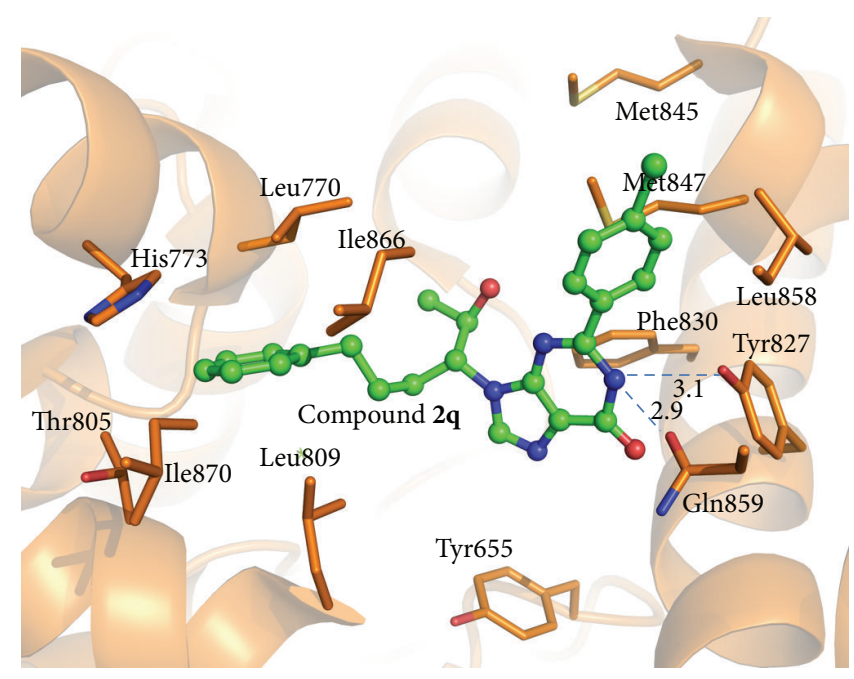

(c)

FIGURE 3: Binding mode of compounds $\mathbf{2 j}(\mathrm{a}), \mathbf{2 p}(\mathrm{b})$, and $\mathbf{2 q}(\mathrm{c})$ in the active site pocket of PDE2. Each ligand is rendered as balls and sticks and the surrounding residues are rendered as sticks. For the convenience of display, some residues and atoms are not shown. See Figure 2 for the color codes of the atom types.

inhibitors. Compound $\mathbf{2 p}$ can be regarded as a good starting structure for the design of new PDE2 inhibitors.

\section{Conclusions}

A series of purin-6-one derivatives were designed and synthesized as potential PDE2 inhibitors. SAR studies suggested that the carbonyl oxygen at 6-position of purin-6-one derivatives played a key role in maintaining the inhibitory activity against PDE2 enzyme. Three more potential compounds $\mathbf{2 j}, \mathbf{2} \mathbf{p}$, and $\mathbf{2 q}$ were identified to have submicromolar $\mathrm{IC}_{50}$ values. Molecular docking of compounds $\mathbf{2 j}, \mathbf{2 p}$, and $\mathbf{2 q}$ into the catalytic domain of the PDE2 revealed a similar binding profile with PDE2 to that of BAY 60-7550. Residue Tyr655, which has been never reported before, was found to be potential binding target for PDE2 inhibitors. The binding mode analysis indicates that optimization of $2 \mathbf{p}$ compound is promising to be a leading structure for the design of novel PDE2 inhibitors.

\section{Experimental Section}

4.1. Chemistry. ${ }^{1} \mathrm{H}$ NMR spectra were recorded on a Varian NMR $600 \mathrm{MHz}$ instrument or Mercury plus $400 \mathrm{MHz}$, and the chemical shifts, $\delta$, are in ppm and tetramethylsilane as internal standard. Graphical ${ }^{1} \mathrm{H}$ NMR spectra of the compounds $2 \mathbf{b}-2 \mathbf{s}$ in this work are collected in the Supplementary Material available online at http://dx.doi.org/10.1155/ 2016/6878353. Mass spectra were determined using Trace MS 2000 organic mass spectrometry, and signals are given in $\mathrm{m} / z$. Melting points were recorded on Büchi B-545 melting point apparatus. Elemental analysis (EA) was carried out with a Vario EL III CHNSO elemental analyzer. Conventional heating was carried out on Corning stirrer/hotplates with oil 
baths. Thin layer chromatography (TLC) inspections were carried out on a silica gel $\mathrm{GF}_{254}$ plates. Triethyl orthoformate, 2-cyano-2-amino-acetamide, and other chemical reagents otherwise noted were commercially available. Solvents were dried in a routine way and redistilled. Esters were prepared using acid as raw materials in the presence of acetyl chloride and alcohol.

4.1.1. General Procedures for Synthesis of the Intermediate 5-Amino-4-carboxamide-1-substituted-1H-imidazole (1). $20 \mathrm{mmol}$ of 2-amino-2-cyanoacetamide was suspended in $30 \mathrm{~mL}$ absolute acetonitrile, and $23 \mathrm{mmol}$ of triethyl orthoformate and $0.03 \mathrm{~g}$ pyridine as a catalyst were added to the suspension with stirring. The suspension was heated to reflux temperature using an oil bath preheated to $100^{\circ} \mathrm{C}$ and the suspension was held at boiling temperature for $1 \mathrm{~h}$ and then $20 \mathrm{mmol}$ of substituted amine was then added over a 3 to $5 \mathrm{~min}$ period and boiling was continued for an additional $15 \mathrm{~min}$. The reaction was quickly cooled to room temperature and then solvent was evaporated, and the residue was recrystallized from DMF-ethanol to give the product.

(1) 5-Amino-1-(2-hydroxyethyl)-1H-imidazole-4-carboxamide (1a). M.p.: $142.6^{\circ} \mathrm{C}$, Yield: $73.2 \%$. ${ }^{1} \mathrm{H}$ NMR $(400 \mathrm{MHz}$, DMSO- $\mathrm{d}_{6}$ ): $\delta, 7.06(\mathrm{~s}, 1 \mathrm{H}, \mathrm{CH}), 6.72,6.58$ (pair of s, br, $2 \mathrm{H}$, $\mathrm{CONH}_{2}$ ), 5.68 (s, 2H, $\mathrm{ArNH}_{2}$ ), 5.03 (s, $\left.1 \mathrm{H}, \mathrm{OH}\right), 3.83$ (t, $2 \mathrm{H}$, $\left.J=5.2 \mathrm{~Hz}, \mathrm{CH}_{2} \mathrm{O}\right), 3.61\left(\mathrm{t}, 2 \mathrm{H}, J=6 \mathrm{~Hz}, \mathrm{CH}_{2} \mathrm{~N}\right)$. EI-MS: $m / z$ (relative intensity) $170.9(\mathrm{M}+1,55), 169.8(97), 125.8(91), 109.8$ (74), 108.7 (100), 44.8 (67).

(2) 5-Amino-1-benzyl-1H-imidazole-4-carboxamide (1c). M.p.: $250.8^{\circ} \mathrm{C}$, Yield: $76 \% .{ }^{1} \mathrm{H}$ NMR $\left(600 \mathrm{MHz}, \mathrm{DMSO}-\mathrm{d}_{6}\right): \delta, 7.19-$ $7.37(\mathrm{~m}, 6 \mathrm{H}, \mathrm{ArH}+\mathrm{CH}), 6.64,6.79$ (pair of s, $2 \mathrm{H}, \mathrm{CONH}_{2}$ ), $5.84\left(\mathrm{~s}, 2 \mathrm{H}, \mathrm{ArNH}_{2}\right), 5.07$ (s, 2H, $\left.\mathrm{ArCH}_{2}\right)$. EI-MS: $m / z$ (relative intensity) $216.2\left(\mathrm{M}^{+}, 23\right), 91.2$ (100), 65.1 (26), 44.3 (7).

(3) 5-Amino-1-(3-phenylpropyl)-1H-imidazole-4-carboxamide (1d). M.p.: $198.1^{\circ} \mathrm{C}$, Yield: $76 \% .{ }^{1} \mathrm{H}$ NMR (600 MHz, DMSO$\left.\mathrm{d}_{6}\right): \delta, 7.17-7.30(\mathrm{~m}, 5 \mathrm{H}, \mathrm{ArH}), 7.11(\mathrm{~s}, 1 \mathrm{H}, \mathrm{CH}), 6.61,6.76$ (pair of s, $\left.2 \mathrm{H}, \mathrm{CONH}_{2}\right), 5.80\left(\mathrm{~s}, 2 \mathrm{H}, \mathrm{NH}_{2}\right), 3.82\left(\mathrm{t}, \mathrm{CH}_{2}\right.$, $J=7.2 \mathrm{~Hz}), 2.50-2.58\left(\mathrm{~m}, 2 \mathrm{H}, \mathrm{CH}_{2}\right), 1.91-1.99\left(\mathrm{~m}, 2 \mathrm{H}, \mathrm{CH}_{2}\right)$. EI-MS: $m / z$ (relative intensity): $244.2(\mathrm{M}, 44), 210.3$ (26), 140.1 (61), 123.1 (82), 117.1 (42), 109 (33), 91.1 (100), 77.0 (18), 65.0 (25), $44.2(14)$.

(4) 5-Amino-1-(4-phenylbutyl)-1H-imidazole-4-carboxamide (1i). M.p.: $222^{\circ} \mathrm{C}$, Yield: $72 \% .{ }^{1} \mathrm{H}$ NMR (600 MHz, DMSO- $\left.\mathrm{d}_{6}\right)$ : $\delta, 7.14-7.27$ (m, 5H, ArH), 7.07 (s, 1H, CH), 6.57, 6.70 (pair of s, $\left.2 \mathrm{H}, \mathrm{CONH}_{2}\right), 5.76\left(\mathrm{~s}, 2 \mathrm{H}, \mathrm{NH}_{2}\right), 3.80\left(\mathrm{t}, \mathrm{CH}_{2}, J=9 \mathrm{~Hz}\right)$, $2.58\left(\mathrm{t}, \mathrm{CH}_{2}, J=7.8 \mathrm{~Hz}\right), 1.62-1.66\left(\mathrm{~m}, 2 \mathrm{H}, \mathrm{CH}_{2}\right), 1.49-1.54$ (m, $2 \mathrm{H}, \mathrm{CH}_{2}$ ). EI-MS: $\mathrm{m} / z$ (relative intensity) $258.5\left(\mathrm{M}^{+}, 51\right)$, 224.2 (22), 213.8 (9), 154.1 (13), 149.9 (22), 137.2 (12), 126.1 (17), 108.9 (28), 91.1 (100), 76.9 (14), 65.0 (26).

(5) 5-Amino-1-[1-(1-hydroxyethyl)-2-phenylethyl]-1H-imidazole-4-carboxamide (1n). M.p.: $231.4^{\circ} \mathrm{C}$, Yield: $67 \% .{ }^{1} \mathrm{H}$ NMR $\left(600 \mathrm{MHz}, \mathrm{DMSO}-\mathrm{d}_{6}\right): \delta, 7.12-7.23(\mathrm{~m}, 6 \mathrm{H}, \mathrm{ArH}), 6.56,6.69$ (pair of s, $\left.2 \mathrm{H}, \mathrm{CONH}_{2}\right), 5.60\left(\mathrm{~s}, 2 \mathrm{H}, \mathrm{NH}_{2}\right), 5.31(\mathrm{~d}, 1 \mathrm{H}, \mathrm{OH}$,
$J=6 \mathrm{~Hz}), 4.18-4.22(\mathrm{~m}, 1 \mathrm{H}, \mathrm{CH}), 3.90-3.93(\mathrm{~m}, 1 \mathrm{H}, \mathrm{CH})$, 3.12-3.26 (m, 2H, CH $\left.\mathrm{CH}_{2}\right), 1.05$ (d, $\left.3 \mathrm{H}, \mathrm{CH}_{3}, J=3 \mathrm{~Hz}\right)$. EI-MS: $\mathrm{m} / z$ (relative intensity) $274.2\left(\mathrm{M}^{+}, 5\right), 166(2), 126(17), 109$ (15), 91.2 (100), 77.0 (17), 65.0 (27), 51.2 (12), 45.3 (60).

(6) 5-Amino-1-[1-(1-hydroxyethyl)-4-phenylbutyl]-1H-imidazole-4-carboxamide (1p). ${ }^{1} \mathrm{H}$ NMR $\left(600 \mathrm{MHz}, \mathrm{DMSO}-\mathrm{d}_{6}\right)$ : $\delta, 7.12-7.26(\mathrm{~m}, 6 \mathrm{H}, \mathrm{ArH}+1 \mathrm{H}$ ), 6.75, 6.60 (pair of s, $2 \mathrm{H}$, $\left.\mathrm{CONH}_{2}\right), 5.74\left(\mathrm{~s}, 2 \mathrm{H}, \mathrm{NH}_{2}\right), 5.13(\mathrm{~d}, 1 \mathrm{H}, \mathrm{OH}, J=1.8 \mathrm{~Hz})$, 3.82-3.83 (m, 2H, CH+CH), 2.53-2.61 (m, 2H, $\left.\mathrm{CH}_{2}\right), 1.80-$ $1.91\left(\mathrm{~m}, 2 \mathrm{H}, \mathrm{CH}_{2}\right), 1.32-1.41\left(\mathrm{~m}, 2 \mathrm{H}, \mathrm{CH}_{2}\right), 0.95$ (d, $3 \mathrm{H}, \mathrm{CH}_{3}$, $J=3 \mathrm{~Hz}$ ). EI-MS: $m / z$ (relative intensity) $303.6(\mathrm{M}+1,13)$, $302.2\left(\mathrm{M}^{+}, 73\right), 268.1$ (25), 240.4 (8), 256.9 (168), 152.9 (208), 126 (100), 108.9 (71), 91.1 (83), 77.0 (13), 65.1 (14), 55.2 (14), $43.1(25)$.

4.1.2. General Procedure for the Preparation of Purin-6-One Derivatives $(2 \boldsymbol{a}-2 \boldsymbol{q}) .1 .4 \mathrm{mmol}$ of 5-amino-1-substituted-4carboxamide-1H-imidazole (1) was dissolved in $10 \mathrm{~mL}$ of absolute methanol. Then $5.6 \mathrm{mmol}$ of the appropriate ester is added into this solution. This mixture was added in $10 \mathrm{~mL}$ of methoxide-methanol solution prepared from sodium $(0.15 \mathrm{~g}$, $6.3 \mathrm{mmol}$ ) and $10 \mathrm{~mL}$ of absolute methanol. The mixture was refluxed for $15-20 \mathrm{~h}$. After cooling, the solvent was evaporated off and the residue was taken into ethyl acetate. The organic phase was dried over $\mathrm{Na}_{2} \mathrm{SO}_{4}$ and evaporated. And the residue was purified via silica gel chromatography (eluent: the mixture of ethyl acetate and methanol) to obtain the pure product $(\mathbf{2} \mathbf{a}-\mathbf{2 q})$.

(1) 9-(2-Hydroxy-ethyl)-2-(3-methoxy-benzyl)-1,9-dihydropurin-6-one (2a). The data of ${ }^{1} \mathrm{H}$ NMR, IR, EI-MS, elemental analysis, and $\mathrm{X}$-ray crystal was reported in our previous study [23].

(2) 2-(3,4-Dimethoxy-benzyl)-9-(2-hydroxy-ethyl)-1,9-dihydro-purin-6-one (2b). M.p.: $223.6^{\circ} \mathrm{C}$, Yield: $76 \%{ }^{1} \mathrm{H}$ NMR $\left(400 \mathrm{MHz}, \mathrm{DMSO}-\mathrm{d}_{6}\right): \delta, 12.27$ (s, NH, 1H), 7.95 (s, CH, $1 \mathrm{H}), 7.02$ (s, ArH, 1H), 6.86-6.93 (m, ArH, 2H), 4.97 (t, $\mathrm{OH}, 1 \mathrm{H}, J=2.8 \mathrm{~Hz}), 4.15\left(\mathrm{t}, \mathrm{CH}_{2}, 2 \mathrm{H}, J=5.2 \mathrm{~Hz}\right), 3.86(\mathrm{~s}$, $\left.\mathrm{CH}_{2}, 2 \mathrm{H}\right), 3.74-3.71\left(8 \mathrm{H}, \mathrm{OCH}_{3}+\mathrm{CH}_{2}\right) .{ }^{13} \mathrm{C} \mathrm{NMR}(100 \mathrm{MHz}$, DMSO- $\left.\mathrm{d}_{6}\right): \delta, 157.8,157.3,149.4,149.1,148.3,141.1,129.4,122.4$, $121.2,113.1,112.3,59.85,56.03,55.95,55.9,46.5$. EI-MS: $m / z$ (relative intensity) $330.0\left(\mathrm{M}^{+}, 100\right), 299.1$ (39), 285.1 (15), 271.0 (33), 239.0 (17), 151.1 (24), 135.1 (23), 109.1 (19), 91.1 (12), 77.1 (16), $65.2(18), 51.2(7), 45.2(13)$. IR $\left(\mathrm{cm}^{-1}\right): 3327(\mathrm{~N}-\mathrm{H})$, 3079, 2939, 1711 (C=O), 1583, 1516, 1439, 1408, 1262, 1237, 1162, 1067, 1058, 1020, 647. Anal. calcd for $\mathrm{C}_{16} \mathrm{H}_{18} \mathrm{~N}_{4} \mathrm{O}_{4}$ : C, 58.17; $\mathrm{H}, 5.49$; N, 16.96. Found: C, 58.15; H, 5.82; N, 16.63.

(3) 9-Benzyl-2-(2-methyl-benzyl)-1,9-dihydro-purin-6-one (2c). The data of ${ }^{1} \mathrm{H}$ NMR, ${ }^{13} \mathrm{C}$ NMR, IR, EI-MS, and elemental analysis was reported in our previous study [25].

(4) 2-(3,4-Dimethoxy-phenyl)-9-(3-phenyl-propyl)-1,9-dihydro-purin-6-one (2d). M.p.: $235.3^{\circ} \mathrm{C}$, Yield: $45 \% .{ }^{1} \mathrm{H}$ NMR $\left(600 \mathrm{MHz}, \mathrm{DMSO}-\mathrm{d}_{6}\right): \delta, 12.33$ (br, s, $\left.1 \mathrm{H}, \mathrm{NH}\right), 8.11(\mathrm{~s}, 1 \mathrm{H}$, $\mathrm{CH}), 7.75$ (s, 1H, ArH), 7.80 (d, 1H, ArH, J = 4.2 Hz), 7.18-7.29 (m, 5H, ArH), 7.11 (d, $1 \mathrm{H}, \mathrm{ArH}, J=4.5 \mathrm{~Hz}), 4.21\left(\mathrm{t}, 2 \mathrm{H}, \mathrm{CH}_{2}\right.$, 
$J=7.2 \mathrm{~Hz}), 3.86\left(\mathrm{~s}, 3 \mathrm{H}, \mathrm{OCH}_{3}\right), 3.85\left(\mathrm{~s}, 3 \mathrm{H}, \mathrm{OCH}_{3}\right), 2.63$ $\left(\mathrm{t}, 2 \mathrm{H}, \mathrm{CH}_{2}, J=7.8 \mathrm{~Hz}\right), 2.17-2.22\left(\mathrm{~m}, 2 \mathrm{H}, \mathrm{CH}_{2}\right) .{ }^{13} \mathrm{C} \mathrm{NMR}$ $\left(100 \mathrm{MHz}, \mathrm{DMSO}-\mathrm{d}_{6}\right): \delta, 158.0,153.0,151.92,159.86,149.4$, $149.0,148.9,141.3,141.0,128.8,126.4,124.9,121.6,112.0,111.3$, 56.2, 56.1, 43.3, 32.6, 31.5. EI-MS: $\mathrm{m} / z$ (relative intensity) $390.2\left(\mathrm{M}^{+}, 75\right), 363.5$ (19), 285.0 (100), 269.1 (10), 198.9 (17), 164.2 (12), 148 (8), 117.2 (13), 104.2 (10), 91.1 (67), 77.2 (13), 65.0 (21), 51.3 (7). IR $\left(\mathrm{cm}^{-1}\right)$ : $3431(\mathrm{~N}-\mathrm{H}), 3093,3012,2933$, 1685 (C=O), 1559, 1539, 1514, 1304, 1269, 1223, 1178, 1024, 876, 754, 702. Anal. calcd for $\mathrm{C}_{22} \mathrm{H}_{22} \mathrm{~N}_{4} \mathrm{O}_{3}$ : C, 67.68; H, 5.68; N, 14.35. Found: C, 68.05; H, 5.38; N, 14.18 .

(5) 2-Benzyl-9-(3-phenyl-propyl)-1,9-dihydro-purin-6-one (2e). M.p.: $225.1^{\circ} \mathrm{C}$, Yield: $62 \% .{ }^{1} \mathrm{H}$ NMR $(600 \mathrm{MHz}$, DMSO$\left.\mathrm{d}_{6}\right): \delta, 12.38(\mathrm{~s}, 1 \mathrm{H}, \mathrm{NH}), 8.04(\mathrm{~s}, 1 \mathrm{H}, \mathrm{CH}), 7.15-7.36(\mathrm{~m}, 10 \mathrm{H}$, ArH), $4.12\left(\mathrm{t}, 2 \mathrm{H}, \mathrm{CH}_{2}, J=7.2\right), 3.96\left(\mathrm{~s}, 2 \mathrm{H}, \mathrm{CH}_{2}\right), 2.54(\mathrm{t}$, $\left.2 \mathrm{H}, \mathrm{CH}_{2}, J=7.8 \mathrm{~Hz}\right), 2.08-2.13\left(\mathrm{~m}, 2 \mathrm{H}, \mathrm{CH}_{2}\right) \cdot{ }^{13} \mathrm{C} \mathrm{NMR}$ $\left(100 \mathrm{MHz}, \mathrm{DMSO}-\mathrm{d}_{6}\right): \delta, 157.8,157.0,149.3,141.3,140.6,137.2$, $129.2,128.9,128.8,128.7,127.3,126.4,122.6,43.4,39.4,32.5$, 31.4. EI-MS: $m / z$ (relative intensity) $344.3\left(\mathrm{M}^{+}, 2\right), 239.2(22)$, 183.1 (6), 117.2 (10), 91.1 (100), 77.2 (22), 65.2 (24), 51.2 (15), 44.2 (29). IR $\left(\mathrm{cm}^{-1}\right): 3442(\mathrm{~N}-\mathrm{H}), 3097,2940,2864,1724$ $(\mathrm{C}=\mathrm{O}), 1581,1494,1453,1410,1361,1128,718,698,654$. Anal. calcd for $\mathrm{C}_{21} \mathrm{H}_{20} \mathrm{~N}_{4} \mathrm{O}$ : C, 73.23; H, 5.85; N, 16.27. Found: C, $73.59 ; \mathrm{H}, 6.10 ; \mathrm{N}, 16.62$.

(6) 2-(2-Methyl-benzyl)-9-(3-phenyl-propyl)-1,9-dihydro-purin-6-one (2f). M.p.: $214.2^{\circ} \mathrm{C}$, Yield: $57 \% .{ }^{1} \mathrm{H}$ NMR $(600 \mathrm{MHz}$, DMSO-d $\left.\mathrm{d}_{6}\right): \delta, 12.33(\mathrm{~s}, 1 \mathrm{H}, \mathrm{NH}), 8.03(\mathrm{~s}, 1 \mathrm{H}, \mathrm{CH}), 7.11-7.26$ $(\mathrm{m}, 9 \mathrm{H}, \mathrm{ArH}), 4.06\left(\mathrm{t}, 2 \mathrm{H}, \mathrm{CH}_{2}, J=7.2 \mathrm{~Hz}\right), 3.97(\mathrm{~s}, 2 \mathrm{H}$, $\left.\mathrm{CH}_{2}\right), 2.50\left(\mathrm{t}, 2 \mathrm{H}, \mathrm{CH}_{2}, J=10.8 \mathrm{~Hz}\right), 2.34\left(\mathrm{~s}, 3 \mathrm{H}, \mathrm{CH}_{3}\right)$, 2.04-2.07 (m, 2H, $\left.\mathrm{CH}_{2}\right) .{ }^{13} \mathrm{C}$ NMR $\left(100 \mathrm{MHz}, \mathrm{DMSO}_{-} \mathrm{d}_{6}\right): \delta$, $157.8,156.9,149.3,141.2,140.59,140.57,137.0,135.7,130.5,129.5$, $128.8,128.6,127.3,126.4,122.6,43.5,38.2,32.5,31.3,19.9$. EIMS: $m / z$ (relative intensity) $358.3\left(\mathrm{M}^{+}, 35\right), 343.2(20), 253.3$ (100), 254.4 (40), 240.3 (16), 228.3 (16), 105.3 (15), 91.2 (52). IR $\left(\mathrm{cm}^{-1}\right): 3433(\mathrm{~N}-\mathrm{H}), 3069,3026,2948,2867,1718(\mathrm{C}=\mathrm{O}), 1582$, $1493,1454,1410,1364,1157,1125,756,695,651$. Anal. calcd for $\mathrm{C}_{22} \mathrm{H}_{22} \mathrm{~N}_{4} \mathrm{O}$ : C, 73.72; H, 6.19; N, 15.63. Found: C, 74.09; H, 6.25; N, 15.98 .

(7) 2-(4-Chloro-phenyl)-9-(3-phenyl-propyl)-1,9-dihydro-purin-6-one (2g). M.p.: 248.4 $4^{\circ} \mathrm{C}$, Yield: $42 \% .{ }^{1} \mathrm{H}$ NMR $(600 \mathrm{MHz}$, DMSO- $\left.\mathrm{d}_{6}\right): \delta, 12.53(\mathrm{~s}, 1 \mathrm{H}, \mathrm{NH}), 8.16(\mathrm{~s}, 1 \mathrm{H}, \mathrm{CH}), 8.13(\mathrm{~d}, 2 \mathrm{H}$, $J=4.2 \mathrm{~Hz}), 7.62(\mathrm{~d}, 2 \mathrm{H}, J=3.9 \mathrm{~Hz}), 7.18-7.29(\mathrm{~m}, 5 \mathrm{H}, \mathrm{ArH})$, $4.22\left(\mathrm{t}, 2 \mathrm{H}, \mathrm{CH}_{2}, J=7.2 \mathrm{~Hz}\right), 2.62\left(\mathrm{t}, 2 \mathrm{H}, \mathrm{CH}_{2}, J=7.2 \mathrm{~Hz}\right)$, 2.17-2.20 (m, $\left.2 \mathrm{H}, \mathrm{CH}_{2}\right)$. EI-MS: $m / z$ (relative intensity) 364 ( $\left.\mathrm{M}^{+}, 23\right), 343.5$ (15), 277.5 (17), 259.0 (100), 240.5 (16), 225.5 (20), 199.4 (12), 118.6 (26), 103.5 (18), 91.0 (43), 77.1 (12), 65.1 (13), 44.3 (21). IR $\left(\mathrm{cm}^{-1}\right): 3433(\mathrm{~N}-\mathrm{H}), 3097,2940,2860,1705$ $(\mathrm{C}=\mathrm{O}), 1549,1493,1452,1411,1364,1128,1090,1008,846,787$, 755, 698, 682. Anal. calcd for $\mathrm{C}_{20} \mathrm{H}_{17} \mathrm{ClN}_{4} \mathrm{O}: \mathrm{C}, 65.84 ; \mathrm{H}, 4.70$; N, 15.36. Found: C, 66.17; H, 5.04; N, 15.03.

(8) 2-(2,4-Dichloro-phenoxymethyl)-9-(3-phenyl-propyl)-1,9dihydro-purin-6-one (2h). M.p.: $188.2^{\circ} \mathrm{C}$, Yield: $66 \% .{ }^{1} \mathrm{H}$ NMR $\left(600 \mathrm{MHz}, \mathrm{DMSO}-\mathrm{d}_{6}\right): \delta, 12.51(\mathrm{~s}, 1 \mathrm{H}, \mathrm{NH}), 8.11(\mathrm{~s}, 1 \mathrm{H}, \mathrm{CH})$, 7.58 (s, 1H, ArH), 7.13-7.34 (m, 7H, ArH), $5.14\left(\mathrm{~s}, 2 \mathrm{H}, \mathrm{CH}_{2}\right)$, $4.11\left(\mathrm{t}, 2 \mathrm{H}, \mathrm{CH}_{2}, J=6.6 \mathrm{~Hz}\right), 2.50\left(\mathrm{t}, 2 \mathrm{H}, \mathrm{CH}_{2}, J=12.6 \mathrm{~Hz}\right)$,
2.03-2.05 ( $\mathrm{m}, 2 \mathrm{H}, \mathrm{CH}_{2}$ ). EI-MS: $\mathrm{m} / z$ (relative intensity) 430.4 $(\mathrm{M}+1,7), 429.5\left(\mathrm{M}^{+}, 7\right), 428.0(18), 393.1(10), 344.5(6), 277.3$ (18), 268.5 (33), 266.9 (70), 240.2 (17), 198.6 (8), 182.9 (8), 164.2 (72), 161.8 (100), 125.9 (12), 98.0 (15), 91.1 (28), 62.6 (21). IR $\left(\mathrm{cm}^{-1}\right): 3441(\mathrm{~N}-\mathrm{H}), 3098,3027,2939,2811,1718(\mathrm{C}=\mathrm{O}), 1600$, $1532,1482,1456,1412,1301,818,753,699,504$. Anal. calcd for $\mathrm{C}_{21} \mathrm{H}_{18} \mathrm{Cl}_{2} \mathrm{~N}_{4} \mathrm{O}_{2}$ : C, 58.75; H, 4.23; N, 13.05. Found: C, 58.39; $\mathrm{H}, 4.11 ; \mathrm{N}, 13.12$.

(9) 2-Benzyl-9-(4-phenyl-butyl)-1,9-dihydro-purin-6-one (2i). M.p.: $197.3^{\circ} \mathrm{C}$, Yield: $73 \% .{ }^{1} \mathrm{H}$ NMR $\left(600 \mathrm{MHz}, \mathrm{DMSO}-\mathrm{d}_{6}\right): \delta$, $12.38(\mathrm{~s}, 1 \mathrm{H}, \mathrm{NH}), 8.04(\mathrm{~s}, 1 \mathrm{H}, \mathrm{CH}), 7.13-7.33(\mathrm{~m}, 10 \mathrm{H}, \mathrm{ArH})$, $4.12\left(\mathrm{t}, 2 \mathrm{H}, \mathrm{CH}_{2}, J=6.6 \mathrm{~Hz}\right), 3.94\left(\mathrm{~s}, 2 \mathrm{H}, \mathrm{CH}_{2}\right), 2.56(\mathrm{t}, 2 \mathrm{H}$, $\left.\mathrm{CH}_{2}, J=7.8 \mathrm{~Hz}\right), 1.76-1.81\left(\mathrm{~m}, 2 \mathrm{H}, \mathrm{CH}_{2}\right), 1.46-1.51(\mathrm{~m}, 2 \mathrm{H}$, $\mathrm{CH}_{2}$ ). EI-MS: $\mathrm{m} / z$ (relative intensity) $358.1\left(\mathrm{M}^{+}, 55.51\right), 330.1$ (28.66), 267.2 (8.26), 253.1 (20.71), 239.1 (26.38), 225.3 (45.65), 213 (9.66), 109.0 (15.93), 91.1 (100.00), 77.0 (10.93), 65.0 (17.75), 55.2 (7.37), $45.2(14.01)$. IR $\left(\mathrm{cm}^{-1}\right): 3427(\mathrm{~N}-\mathrm{H}), 3103,3061$, 2936, 2860, $1723(\mathrm{C}=\mathrm{O}), 1578,1454,1412,1373,1357,1127,944$, 748, 698, 658. Anal. calcd for $\mathrm{C}_{22} \mathrm{H}_{22} \mathrm{~N}_{4} \mathrm{O}$ : C, 73.72; H, 6.19; $\mathrm{N}, 15.63$. Found: C, 73.79; H, 6.14; N, 15.93 .

(10) 2-(3-Methoxy-benzyl)-9-(4-phenyl-butyl)-1,9-dihydropurin-6-one (2j). M.p.: $177.3^{\circ} \mathrm{C}$, Yield: $41 \% .{ }^{1} \mathrm{H}$ NMR $\left(600 \mathrm{MHz}, \mathrm{DMSO}-\mathrm{d}_{6}\right): \delta, 12.34(\mathrm{~s}, 1 \mathrm{H}, \mathrm{NH}), 8.03(\mathrm{~s}, 1 \mathrm{H}, \mathrm{CH})$, 7.12-7.26 (m, 6H, ArH), 6.95 (s, 1H, ArH), 6.88 (d, 1H, ArH, $J=3.6 \mathrm{~Hz}), 6.81(\mathrm{~d}, 1 \mathrm{H}, \mathrm{ArH}, J=3.9 \mathrm{~Hz}), 4.13\left(\mathrm{t}, 2 \mathrm{H}, \mathrm{CH}_{2}\right.$, $J=6.6 \mathrm{~Hz}), 3.91\left(\mathrm{~s}, 2 \mathrm{H}, \mathrm{CH}_{2}\right), 3.71\left(\mathrm{~s}, 3 \mathrm{H}, \mathrm{OCH}_{3}\right), 2.56(\mathrm{t}$, $\left.2 \mathrm{H}, \mathrm{CH}_{2}, J=7.2 \mathrm{~Hz}\right), 1.78-1.80\left(\mathrm{~m}, 2 \mathrm{H}, \mathrm{CH}_{2}\right), 1.48-1.51(\mathrm{~m}$, $\left.2 \mathrm{H}, \mathrm{CH}_{2}\right) .{ }^{13} \mathrm{C}$ NMR $(100 \mathrm{MHz}$, DMSO-d 6 ) $\delta 159.7,157.8$, $156.9,149.3,142.2,140.6,138.5,130.0,128.7,128.7,126.2,122.5$, $121.3,115.1,112.6,55.4,43.3,40.7,34.8,29.5,28.3$. EI-MS: $\mathrm{m} / \mathrm{z}$ (relative intensity) $388.2\left(\mathrm{M}^{+}, 59\right), 342.9(22), 283.9$ (32), 269.0 (35), 255.2 (74), 239.5 (23), 225.8 (60), 212.4 (23), 182.8 (33), 160.8 (28), 147.3 (29), 131.2 (37), 109.0 (38), 102.8 (39), $90.6(100), 76.6(28), 44.3(27)$. IR $\left(\mathrm{cm}^{-1}\right): 3433(\mathrm{~N}-\mathrm{H})$, 3085, 2938, 1673 (C=O), 1582, 1453, 1379, 1257, 1146, 1049, 747, 700. Anal. calcd for $\mathrm{C}_{23} \mathrm{H}_{24} \mathrm{~N}_{4} \mathrm{O}_{2}: \mathrm{C}, 71.11 ; \mathrm{H}, 6.23 ; \mathrm{N}, 14.42$. Found: C, 71.39; H, 6.20; N, 14.78 .

(11) 2-(2-Methyl-benzyl)-9-(4-phenyl-butyl)-1,9-dihydro-purin-6-one (2k). M.p.: $219.4^{\circ} \mathrm{C}$, Yield: $62 \% .{ }^{1} \mathrm{H}$ NMR $(600 \mathrm{MHz}$, DMSO- $\left.\mathrm{d}_{6}\right): \delta, 12.31(\mathrm{~s}, 1 \mathrm{H}, \mathrm{NH}), 8.02(\mathrm{~s}, 1 \mathrm{H}, \mathrm{CH}), 7.10-$ $7.25(\mathrm{~m}, 9 \mathrm{H}, \mathrm{ArH}), 4.06\left(\mathrm{t}, 2 \mathrm{H}, \mathrm{CH}_{2}, J=6.6 \mathrm{~Hz}\right), 3.96$ (s, $\left.2 \mathrm{H}, \mathrm{CH}_{2}\right), 2.32\left(\mathrm{~s}, 3 \mathrm{H}, \mathrm{CH}_{3}\right), 1.73-1.75\left(\mathrm{~m}, 2 \mathrm{H}, \mathrm{CH}_{2}\right)$, 1.42-1.45 (m, 2H, $\mathrm{CH}_{2}$ ). EI-MS: $\mathrm{m} / z$ (relative intensity) 372.3 $\left(\mathrm{M}^{+}, 12.41\right), 344.3$ (19.98), 253.3 (14.56), 240.3 (100.00), 224.3 (14.22), $91.2(29.45), 76.4(7.32)$. IR $\left(\mathrm{cm}^{-1}\right): 3440(\mathrm{~N}-\mathrm{H}), 3102$, 3026, 2942, 2860, $1723(\mathrm{C}=\mathrm{O}), 1582,1559,1493,1452,1410$, $1364,1159,1123,759,696,652$. Anal. calcd for $\mathrm{C}_{23} \mathrm{H}_{24} \mathrm{~N}_{4} \mathrm{O}$ : C, 74.17; H, 6.49; N, 15.04. Found: C, 74.21; H, 6.45; N, 15.34 .

(12) 2-(2,4-Dichloro-phenoxymethyl)-9-(4-phenyl-butyl)-1,9dihydro-purin-6-one (2l). M.p.: 208.6 $6^{\circ}$, Yield: $72 \% .{ }^{1} \mathrm{H}$ NMR $\left(600 \mathrm{MHz}\right.$, DMSO-d $\left.\mathrm{d}_{6}\right): \delta, 12.51(\mathrm{~s}, 1 \mathrm{H}, \mathrm{NH}), 8.09(\mathrm{~s}$, $1 \mathrm{H}, \mathrm{CH}), 7.60$ (s, $1 \mathrm{H}, \mathrm{ArH}), 7.36(\mathrm{~d}, 1 \mathrm{H}, \mathrm{ArH}, J=4.5 \mathrm{~Hz})$, 7.12-7.25 (m, 6H, $\mathrm{ArH}), 5.14\left(\mathrm{~s}, 2 \mathrm{H}, \mathrm{CH}_{2}\right), 4.10$ (t, $2 \mathrm{H}, \mathrm{CH}_{2}$, $J=6 \mathrm{~Hz}), 2.50-2.53\left(2 \mathrm{H}, \mathrm{CH}_{2}\right), 1.69-1.72\left(\mathrm{~m}, 2 \mathrm{H}, \mathrm{CH}_{2}\right)$, 
1.40-1.44 (m, 2H, $\mathrm{CH}_{2}$ ). EI-MS: $m / z$ (relative intensity) 443.6 $\left(\mathrm{M}^{+}, 71\right), 442.3$ (51), 372.4 (29), 369.2 (40), 356.4 (99), 328.8 (54), 296.2 (28), 256.1 (100), 239.0 (44), 211.8 (70), 160.8 (39), 103.2 (72), 91.2 (37), 77.3 (59), 76.2 (74), 51.3 (24), 43.2 (36). IR $\left(\mathrm{cm}^{-1}\right): 3437(\mathrm{~N}-\mathrm{H}), 3098,3028,2932,2862,1718(\mathrm{C}=\mathrm{O})$, 1602, 1481, 1456, 1411, 1234, 820, 720, 699, 651, 506. Anal. calcd for $\mathrm{C}_{22} \mathrm{H}_{20} \mathrm{Cl}_{2} \mathrm{~N}_{4} \mathrm{O}_{2}$ : C, 59.60; $\mathrm{H}, 4.55 ; \mathrm{N}, 12.64$. Found: C, 59.31; H, 4.23; N, 12.31 .

(13) 2-(4-Chloro-phenyl)-9-(4-phenyl-butyl)-1,9-dihydro-purin-6-one (2m). M.p.: 228.1 ${ }^{\circ}$ C, Yield: 30\%. ${ }^{1} \mathrm{H} \mathrm{NMR}(600 \mathrm{MHz}$, DMSO- $\left.\mathrm{d}_{6}\right): \delta, 12.52(\mathrm{~s}, 1 \mathrm{H}, \mathrm{NH}), 8.14(\mathrm{~s}, 1 \mathrm{H}, \mathrm{CH}), 8.11(\mathrm{~d}, 2 \mathrm{H}$, $J=4.2 \mathrm{~Hz}), 7.61(\mathrm{~d}, 2 \mathrm{H}, J=4.2 \mathrm{~Hz}), 7.14-7.24(\mathrm{~m}, 5 \mathrm{H}, \mathrm{ArH})$, $4.23\left(\mathrm{t}, 2 \mathrm{H}, \mathrm{CH}_{2}, J=6.6 \mathrm{~Hz}\right), 2.62\left(\mathrm{t}, 2 \mathrm{H}, \mathrm{CH}_{2}, J=7.2 \mathrm{~Hz}\right)$, 1.85-1.87 (m, 2H, $\left.\mathrm{CH}_{2}\right), 1.54-1.57\left(\mathrm{~m}, 2 \mathrm{H}, \mathrm{CH}_{2}\right)$. EI-MS: $m / z$ (relative intensity) $379.3(\mathrm{M}+1,24), 378.1\left(\mathrm{M}^{+}, 49\right), 337.9(30)$, 274.9 (14), 259.3 (38), 224.3 (3), 164.3 (13),109.3 (17), 91.1 (100). IR $\left(\mathrm{cm}^{-1}\right): 3435(\mathrm{~N}-\mathrm{H})$ 3103, 3026, 2937, 2859, $1688(\mathrm{C}=\mathrm{O})$, 1600, 1549, 1494, 1454, 1411, 1367, 1090, 1011, 842, 787, 732, 699, 498, 472. Anal. calcd for $\mathrm{C}_{21} \mathrm{H}_{19} \mathrm{ClN}_{4} \mathrm{O}: \mathrm{C}, 66.58 ; \mathrm{H}, 5.05 ; \mathrm{N}$, 14.79. Found: C, 66.28; H, 4.88; N, 14.46.

(14) 2-Benzyl-9-(1-benzyl-2-hydroxy-propyl)-1,9-dihydro-purin-6-one (2n). M.p.: $225.2^{\circ} \mathrm{C}$, Yield: $66 \% .{ }^{1} \mathrm{H} \mathrm{NMR}(600 \mathrm{MHz}$, $\mathrm{CDCl}_{3}$ ): $\delta, 12.49$ (s, 1H, NH), 6.83-7.42 (m, 11H, ArH), 4.38$4.40\left(\mathrm{~m}, 2 \mathrm{H}, \mathrm{CH}_{2}\right), 4.13\left(\mathrm{~s}, 2 \mathrm{H}, \mathrm{CH}_{2}\right), 3.21-3.31\left(\mathrm{~m}, 2 \mathrm{H}, \mathrm{CH}_{2}\right)$, 1.39 (d, $3 \mathrm{H}, \mathrm{CH}_{3}, J=3 \mathrm{~Hz}$ ). EI-MS: $m / z$ (relative intensity): $374.4\left(\mathrm{M}^{+}, 22\right), 330.4$ (27), 329.2 (24), 283.3 (7), 226.3 (83), 225.0 (57), 102.8 (21), 91.1 (100), 77.0 (17), 65.0 (22), 45.3 (18). IR $\left(\mathrm{cm}^{-1}\right)$ : 3214, $1677(\mathrm{C}=\mathrm{O}), 1591,1455,1374,716,691$. Anal. calcd for $\mathrm{C}_{22} \mathrm{H}_{22} \mathrm{~N}_{4} \mathrm{O}_{2}$ : C, 70.57; H, 5.92; N, 14.96. Found: C, 70.39; H, 5.84; N, 14.77 .

(15) 9-(1-Benzyl-2-hydroxy-propyl)-2-(2-methyl-benzyl)-1,9dihydro-purin-6-one (2o). M.p.: $86.6^{\circ} \mathrm{C}$, Yield: $88 \% .{ }^{1} \mathrm{H}$ NMR $\left(600 \mathrm{MHz}, \mathrm{DMSO}-\mathrm{d}_{6}\right): \delta, 12.24(\mathrm{~s}, 1 \mathrm{H}, \mathrm{NH}), 7.99$ (s, $1 \mathrm{H}, \mathrm{CH}), 6.88-7.21$ (m, 10H, ArH), 4.42-4.45 (m, 1H, CH), 3.93-4.04 (m, $1 \mathrm{H}, \mathrm{CH}), 3.91\left(\mathrm{~s}, 2 \mathrm{H}, \mathrm{CH}_{2}\right), 3.21-3.23(\mathrm{~m}$, $1 \mathrm{H}, \mathrm{CH}), 2.32\left(\mathrm{~s}, 3 \mathrm{H}, \mathrm{CH}_{3}\right), 0.91\left(\mathrm{~d}, 3 \mathrm{H}, \mathrm{CH}_{3}, J=3 \mathrm{~Hz}\right)$. ${ }^{13} \mathrm{C}$ NMR $\left(100 \mathrm{MHz}, \mathrm{DMSO}-\mathrm{d}_{6}\right): \delta, 157.7,156.5,149.3,140.1$, $138.4,136.99,135.7,130.5,129.4,128.9,128.5,127.3,126.5,126.3$, 122.3, 68.4, 63.1, 38.1, 35.6, 20.7, 19.9. EI-MS: $m / z$ (relative intensity) $388.3\left(\mathrm{M}^{+}, 99\right), 342.6(25), 240.3$ (100), 223.4 (26), 212.3 (21), 131.3 (35), 91.1 (17), 76.8 (16), 42.9 (17). IR $\left(\mathrm{cm}^{-1}\right)$ : 3389 (N-H), 3087, 2970, 1680 (C=O), 1586, 1495, 1456, 1408, $1372,1154,1124,746,701,650$. Anal. calcd for $\mathrm{C}_{23} \mathrm{H}_{24} \mathrm{~N}_{4} \mathrm{O}_{2}$ : C, 71.11; H, 6.23; N, 14.42. Found: C, 71.09; H, 6.50; N, 14.07 .

(16) 2-Benzyl-9-[1-(1-hydroxy-ethyl)-4-phenyl-butyl]-1,9-dihydro-purin-6-one (2p). M.p.: $180.4^{\circ} \mathrm{C}$, Yield: $78 \%$. ${ }^{1} \mathrm{H}$ NMR $\left(600 \mathrm{MHz}, \mathrm{DMSO}-\mathrm{d}_{6}\right): \delta, 12.38(\mathrm{~s}, 1 \mathrm{H}, \mathrm{NH}), 8.05(\mathrm{~s}, 1 \mathrm{H}, \mathrm{CH})$, $7.02-7.33(\mathrm{~m}, 10 \mathrm{H}, \mathrm{ArH}), 5.14(\mathrm{~d}, 1 \mathrm{H}, \mathrm{OH}, J=5.4 \mathrm{~Hz}), 4.22-$ $4.26(\mathrm{~m}, 1 \mathrm{H}, \mathrm{CH}), 3.94\left(3 \mathrm{H}, \mathrm{CH}_{2}+\mathrm{CH}\right), 2.41-2.45(\mathrm{~m}, 2 \mathrm{H}$, $\left.\mathrm{CH}_{2}\right), 2.00-2.06\left(\mathrm{~m}, 2 \mathrm{H}, \mathrm{CH}_{2}\right), 1.21-1.29\left(\mathrm{~m}, 2 \mathrm{H}, \mathrm{CH}_{2}\right), 0.87$ $\left(\mathrm{d}, 3 \mathrm{H}, \mathrm{CH}_{3}, J=6 \mathrm{~Hz}\right)$. IR $\left(\mathrm{cm}^{-1}\right): 3397(\mathrm{~N}-\mathrm{H}), 3085,3026$, 2934, $1666(\mathrm{C}=\mathrm{O}), 1581,1402,1372,749$, 699. Anal. calcd for: $\mathrm{C}_{24} \mathrm{H}_{26} \mathrm{~N}_{4} \mathrm{O}_{2}$ : C, 71.62; H, 6.51; N, 13.92. Found: C, 71.39; H, $6.58 ; \mathrm{N}, 14.04$.
(17) 2-(4-Chloro-phenyl)-9-[1-(1-hydroxy-ethyl)-4-phenyl-butyl]-1,9-dihydro-purin-6-one (2q): The Mixture of Isomers (1: 1). M.p.: $263.4^{\circ} \mathrm{C}$, Yield: $39 \% .{ }^{1} \mathrm{H}$ NMR $(600 \mathrm{MHz}$, DMSO$\left.\mathrm{d}_{6}\right): \delta, 12.54(\mathrm{~s}, 1 \mathrm{H}, \mathrm{NH}), 8.16(\mathrm{~s}, 1 \mathrm{H}, \mathrm{CH}), 8.11-8.13(\mathrm{~m}, 3 \mathrm{H}$, ArH), 8.07 (s, 1H, ArH), 7.61 (d, 4H, ArH), 5.15 (dd, 1H, OH, $J=6 \mathrm{~Hz}), 4.35-4.45(\mathrm{~m}, 1 \mathrm{H}, \mathrm{CH}), 4.04-4.10(\mathrm{~m}, 1 \mathrm{H}, \mathrm{CH})$, 2.51-2.63 (m, 2H, $\left.\mathrm{CH}_{2}\right), 1.87-2.11\left(\mathrm{~m}, 2 \mathrm{H}, \mathrm{CH}_{2}\right), 1.29-1.41(\mathrm{~m}$, $\left.2 \mathrm{H}, \mathrm{CH}_{2}\right), 0.95\left(\mathrm{~d}, 3 \mathrm{H}, \mathrm{CH}_{3}, J=6 \mathrm{~Hz}\right.$ ). EI-MS: $m / z$ (relative intensity) $423.0\left(\mathrm{M}^{+}, 4\right), 246.9$ (3), 138.1 (7), 104.2 (7), 91.1 (100), 77.2 (10), 65.0 (17), 51.2 (6), 45.1 (37). IR $\left(\mathrm{cm}^{-1}\right): 3436$ (N-H), 3084, 2930, 1687 (C=O), 1599, 1548, 1492, 1367, 1089, 840, 699, 549. Anal. calcd for: $\mathrm{C}_{23} \mathrm{H}_{23} \mathrm{ClN}_{4} \mathrm{O}_{2}$ : C, 65.32; $\mathrm{H}$, 5.48; N, 13.25. Found: C, 65.66; H, 6.59; N, 13.58.

\subsubsection{General Procedures of Synthesis of $2 r$ and $2 s$}

(1) 2-Benzyl-9-(1-benzyl-2-oxo-propyl)-1,9-dihydro-purin-6one (2r). $15 \mathrm{~mL}$ of absolute dichloromethane and triethylamine $(5.22 \mathrm{~g}, 6.39 \mathrm{mmol})$ was added to $2 \mathrm{n}(0.58 \mathrm{~g}$, $1.55 \mathrm{mmol}$ ) and the mixture was cooled to $0^{\circ} \mathrm{C}$ using an ice-bath. $1.5 \mathrm{~mL}$ of DMSO and $3.26 \mathrm{~g}$ of pyridine/sulphur trioxide complex were added, and the mixture was then under an atmosphere of nitrogen, stirred in ice bath for $1 \mathrm{~h}$, and heated at $60^{\circ} \mathrm{C}$ for further $6 \mathrm{~h} .20 \mathrm{~mL}$ of water was added to the solution, and the mixture was extracted three times with in each case $25 \mathrm{~mL}$ of dichloromethane. The organic phases were washed with water and then dried over sodium sulfate and concentrated using a rotary evaporator. The crude product was purified by chromatography to give $0.43 \mathrm{~g}$ of title compound.

M.p.: $60^{\circ} \mathrm{C}$, Yield: $74.7 \% .{ }^{1} \mathrm{H}$ NMR $\left(600 \mathrm{MHz} \mathrm{CDCl}_{3}\right)$ : $\delta, 12.84$ (br, $1 \mathrm{H}, \mathrm{NH}), 7.75$ (s, 1H, CH), 6.96-7.38 (m, 10H, $\mathrm{ArH}), 5.40(\mathrm{dd}, 1 \mathrm{H}, \mathrm{CH}, J=5.4 \mathrm{~Hz}, J=10.2 \mathrm{~Hz}), 4.07(\mathrm{~s}$, $2 \mathrm{H}, \mathrm{CH}_{2}$ ), $3.57(\mathrm{dd}, 1 \mathrm{H}, \mathrm{CH}, J=5.4 \mathrm{~Hz}, J=14.4 \mathrm{~Hz}), 3.29$ (dd, $1 \mathrm{H}, \mathrm{CH}, J=10.2 \mathrm{~Hz}, J=13.8 \mathrm{~Hz}), 2.18\left(\mathrm{~s}, 3 \mathrm{H}, \mathrm{CH}_{3}\right)$. ${ }^{13} \mathrm{C} \mathrm{NMR}\left(100 \mathrm{MHz}, \mathrm{CDCl}_{3}\right.$ ): $\delta, 202.47,159.49,149.46,157.5$, 149.62, 139.1, 135.5, 135.3, 129.3, 128.9, 128.7, 127.4, 127.3, 122.1, 64.3, 41.3, 36.9, 28.0. EI-MS: $m / z$ (relative intensity) 372.0 $\left(\mathrm{M}^{+}, 16\right), 329.2(100), 224.9(38), 212.7(8), 102.8(33), 91.1(79)$, 76.9 (19), $65.0(21), 51.2(7), 43.2(43)$. IR $\left(\mathrm{cm}^{-1}\right): 3440(\mathrm{~N}-\mathrm{H})$, 3087, 3029, 2922, $1684(\mathrm{C}=\mathrm{O}), 1580,1455,1410,717,699$. Anal. calcd for: $\mathrm{C}_{22} \mathrm{H}_{20} \mathrm{~N}_{4} \mathrm{O}_{2}$ : C, 70.95; H, 5.41; N, 15.04. Found: C, 70.76; H, 5.73; N, 14.56 .

(2) 9-(1-Benzyl-2-oxo-propyl)-2-(2-methyl-benzyl)-1,9-dihydro-purin-6-one (2s). 2 s was prepared by oxidating 20 using similar method to that of compound $2 \mathbf{r}$.

M.p.: $209.0^{\circ} \mathrm{C}$, Yield: $72 \% .{ }^{1} \mathrm{H}$ NMR $\left(600 \mathrm{MHz}, \mathrm{CDCl}_{3}\right)$ : $\delta, 12.12(\mathrm{~s}, 1 \mathrm{H}, \mathrm{NH}), 7.72(\mathrm{~s}, 1 \mathrm{H}, \mathrm{CH}), 6.94-7.28$ (m, 9H, ArH), $5.30\left(\mathrm{dd}, 1 \mathrm{H}, \mathrm{CH}_{2}, J=5.4 \mathrm{~Hz}, J=9 \mathrm{~Hz}\right), 3.52\left(\mathrm{dd}, 1 \mathrm{H}, \mathrm{CH}_{2}\right.$, $J=5.4 \mathrm{~Hz}, J=14.4 \mathrm{~Hz}), 3.24\left(\mathrm{dd}, 1 \mathrm{H}, \mathrm{CH}_{2}, J=13.8 \mathrm{~Hz}\right.$, $J=10.2 \mathrm{~Hz}), 2.31$ (s, 3H, $\left.\mathrm{CH}_{3}\right), 2.10$ (s, 3H, $\left.\mathrm{CH}_{3} \mathrm{CO}\right)$. EI-MS: $\mathrm{m} / z$ (relative intensity) $386.4\left(\mathrm{M}^{+}, 8\right), 342.8(17), 298.5$ (13), 225.3 (30), 199.5 (9), 171.3 (12), 143.2 (19), 103.3 (35), 91.0 (100), 77.2 (10), 65.2 (12), 43.6 (8). ${ }^{13} \mathrm{C}$ NMR (101 MHz, DMSO$\left.\mathrm{d}_{6}\right) \delta 203.6,157.6,157.1,149.2,140.5,137.0,135.6,130.5,129.4$, $129.0,128.7,127.3,127.0,126.3,122.3,64.9,38.1,35.1,27.5,19.9$. IR $\left(\mathrm{cm}^{-1}\right): 3440(\mathrm{~N}-\mathrm{H}), 3081,3025,2905,1731(\mathrm{C}=\mathrm{O}), 1660$, $1587,1458,1408,1354,1234,1174,748,732,655$. Anal. calcd for: 
$\mathrm{C}_{23} \mathrm{H}_{22} \mathrm{~N}_{4} \mathrm{O}_{2}$ : C, 71.48; $\mathrm{H}, 5.74 ; \mathrm{N}, 14.50$. Found: C, 71.31; $\mathrm{H}$, $6.09 ; \mathrm{N}, 14.48$.

4.1.4. The Procedure for Synthesis of $2 c-1$ and $2 c-2$ [26]. A mixture of $2 \mathrm{c}(0.22 \mathrm{~g})$ and $\mathrm{NaH}(70 \%, 0.04 \mathrm{~g})$ in $6 \mathrm{~mL}$ of dry DMF was stirred at room temperature for $0.5 \mathrm{~h}$; then ally bromide $(0.15 \mathrm{~g})$ was added to this solution and stirred for $4.5 \mathrm{~h}$ at the same temperature. And ice-water $(100 \mathrm{~mL})$ was added to the solution with stirring; the solid deposited was filtered and washed with water. The two regioisomers cropped were separated by column chromatography on silica gel using the mixture of petroleum ether and EtOAc as eluting solvent to afford the corresponding $\mathbf{2 c - 1}(0.08 \mathrm{~g})$ and $\mathbf{2 c - 2}(0.13 \mathrm{~g})$ as the first and second fractions, respectively.

(1) 1-Allyl-9-benzyl-2-(2-methyl-benzyl)-1,9-dihydro-purin-6one 2c-1. M.p.: $82^{\circ} \mathrm{C}$, Yield: $33 \% .{ }^{1} \mathrm{H}$ NMR $(600 \mathrm{MHz}$, DMSO$\left.\mathrm{d}_{6}\right): \delta, 8.21(\mathrm{~s}, 1 \mathrm{H}, \mathrm{CH}), 7.02-7.30(\mathrm{~m}, 9 \mathrm{H}, \mathrm{ArH}), 5.99-6.00(\mathrm{~m}$, $\left.1 \mathrm{H}, \mathrm{CH}_{2}\right), 5.09\left(\mathrm{dd}, 2 \mathrm{H}, \mathrm{CH}_{2}, J=52.2 \mathrm{~Hz}, J=62.4 \mathrm{~Hz}\right.$ ), 5.08 $\left(\mathrm{s}, 2 \mathrm{H}, \mathrm{CH}_{2}\right), 4.75-4.98\left(\mathrm{~m}, 2 \mathrm{H}, \mathrm{CH}_{2}\right), 4.20\left(\mathrm{~s}, 3 \mathrm{H}, \mathrm{CH}_{3}\right), 2.14$ (s, $3 \mathrm{H}, \mathrm{CH}_{3}$ ). EI-MS: $m / z$ (relative intensity) $370.1\left(\mathrm{M}^{+}, 16\right)$, 355.0 (10), 278.9 (6), 265.3 (8), 238.2 (6), 171.1 (19), 105.0 (21), $91.3(100), 76.8(8), 65.0(22), 44.2(6)$. IR $\left(\mathrm{cm}^{-1}\right): 3442,3085$, 2945, 1689 (C=O), 1553, 1515, 1354, 1186, 750, 718. Anal. calcd for: $\mathrm{C}_{23} \mathrm{H}_{22} \mathrm{~N}_{4} \mathrm{O}: \mathrm{C}, 74.57 ; \mathrm{H}, 5.99 ; \mathrm{N}, 15.12$. Found: C, 73.91; $\mathrm{H}, 5.79 ; \mathrm{N}, 15.39$.

(2) 6-Allyloxy-9-benzyl-2-(2-methyl-benzyl)-9H-purine 2c-2. M.p.: $133.5^{\circ} \mathrm{C}$, Yield: $53 \% .{ }^{1} \mathrm{H}$ NMR $\left(600 \mathrm{MHz}, \mathrm{DMSO}-\mathrm{d}_{6}\right)$ : $\delta, 8.44(\mathrm{~s}, 1 \mathrm{H}, \mathrm{CH}), 7.11-7.31(\mathrm{~m}, 9 \mathrm{H}, \mathrm{ArH}), 6.02-6.09(\mathrm{~m}, 1 \mathrm{H}$, $\mathrm{CH}), 5.39\left(\mathrm{~s}, 2 \mathrm{H}, \mathrm{CH}_{2}\right), 5.36(\mathrm{~d}, 1 \mathrm{H}, \mathrm{CH}, J=1.2 \mathrm{~Hz}), 5.24(\mathrm{~d}$, $1 \mathrm{H}, \mathrm{CH}, J=10.2 \mathrm{~Hz}), 4.99\left(\mathrm{~d}, 1 \mathrm{H}, \mathrm{CH}_{2}\right), 4.17\left(\mathrm{~s}, 2 \mathrm{H}, \mathrm{CH}_{2}\right)$, $2.32\left(\mathrm{~s}, 3 \mathrm{H}, \mathrm{CH}_{3}\right)$. EI-MS: $\mathrm{m} / z$ (relative intensity) $370.2\left(\mathrm{M}^{+}\right.$, 3), 128.8 (5), 105.1 (12), 91.1 (100), 89.3 (10), 65.1 (25), 55.2 (8), 44.1 (18). IR $\left(\mathrm{cm}^{-1}\right): 3417,3077,2944,1597,1574,1445,1410$, $1375,1245,1065,935,741,643$. Anal. calcd for: Anal. calcd for: $\mathrm{C}_{23} \mathrm{H}_{22} \mathrm{~N}_{4} \mathrm{O}$ : C, 74.57; H, 5.99; N, 15.12. Found: C, 74.39; H, 5.53; N, 14.98 .

4.2. Enzymatic Activities of Recombinant Human PDE2 Using an In Vitro Enzymatic Assay. The enzyme inhibitory activities of the synthesized compounds were evaluated against PDE2 using recombinant human PDE2 by BPS Bioscience Inc. (San Diego, California, USA) using fluorescence polarization method. Tested compounds were dissolved in DMSO and diluted in assay buffer (final DMSO concentration 1\%, final inhibitor concentration $10 \mu \mathrm{M}$ ). PDE activity assays were performed in duplicate at each concentration. The reaction was conducted at room temperature for 60 minutes in a $50 \mu \mathrm{L}$ mixture containing reaction buffer, $100 \mathrm{nM}$ FAMcAMP as substrate, $1 \mu \mathrm{M}$ cGMP, recombinant human PDE2 $(0.75 \mathrm{ng} /$ reaction $)$, and a tested compound. Fluorescence intensity was measured at an excitation of $485 \mathrm{~nm}$ and an emission of $528 \mathrm{~nm}$ using BioTek Synergy ${ }^{\text {tm }} 2$ microplate reader (San Diego, California, USA).

Fluorescence intensity was converted to fluorescence polarization using the Gen5 software. The fluorescence polarization data were analyzed using the computer software, GraphPad Prism (GraphPad Software Inc., San Diego, CA).
The value of fluorescence polarization $\left(\mathrm{FP}_{t}\right)$ from the reactions without the compound was defined as $100 \%$ activity. In the absence of PDE2 and the compound, the value of fluorescent polarization $\left(\mathrm{FP}_{b}\right)$ was defined as $0 \%$ activity. The percent activity in the presence of the compound was calculated according to the following equation: activity $\%=$ $\left(\mathrm{FP}-\mathrm{FP}_{b}\right) /\left(\mathrm{FP}_{t}-\mathrm{FP}_{b}\right) \times 100 \%$. In the equation, $\mathrm{FP}$ is the fluorescence polarization in the presence of the compound.

\section{Conflict of Interests}

The authors declare that there is no conflict of interests regarding the publication of this paper.

\section{Acknowledgments}

The research was supported in part by National Institutes of Health (Grant RC1MH088480), National Natural Science Foundation of China (Grant 21273089), and the Special Fund for Basic Scientific Research of Central Colleges, SouthCentral University for Nationalities (CZY14004).

\section{References}

[1] M. J. Speakman, "PDE5 inhibitors in the treatment of LUTS," Current Pharmaceutical Design, vol. 15, no. 30, pp. 3502-3505, 2009.

[2] Y.-J. Wang, Y.-L. Jiang, H.-F. Tang, C.-Z. Zhao, and J.-Q. Chen, "Zl-n-91, a selective phosphodiesterase 4 inhibitor, suppresses inflammatory response in a COPD-like rat model," International Immunopharmacology, vol. 10, no. 2, pp. 252-258, 2010.

[3] A. T. Bender and J. A. Beavo, "Cyclic nucleotide phosphodiesterases: molecular regulation to clinical use," Pharmacological Reviews, vol. 58, no. 3, pp. 488-520, 2006.

[4] C. Lugnier, "Cyclic nucleotide phosphodiesterase (PDE) superfamily: a new target for the development of specific therapeutic agents," Pharmacology \& Therapeutics, vol. 109, no. 3, pp. 366398, 2006.

[5] K. Omori and J. Kotera, "Overview of PDEs and their regulation," Circulation Research, vol. 100, no. 3, pp. 309-327, 2007.

[6] H. L. Trong, N. Beier, W. K. Sonnenburg et al., "Amino acid sequence of the cyclic GMP stimulated cyclic nucleotide phosphodiesterase from bovine heart," Biochemistry, vol. 29, no. 44, pp. 10280-10288, 1990.

[7] E. Reyes-Irisarri, M. Markerink-Van Ittersum, G. Mengod, and J. De Vente, "Expression of the cGMP-specific phosphodiesterases 2 and 9 in normal and Alzheimer's disease human brains," The European Journal of Neuroscience, vol. 25, no. 11, pp. 3332-3338, 2007.

[8] F. G. Boess, M. Hendrix, F.-J. van der Staay et al., "Inhibition of phosphodiesterase 2 increases neuronal cGMP, synaptic plasticity and memory performance," Neuropharmacology, vol. 47, no. 7, pp. 1081-1092, 2004.

[9] K. Domek-Łopacińska and J. B. Strosznajder, "The effect of selective inhibition of cyclic GMP hydrolyzing phosphodiesterases 2 and 5 on learning and memory processes and nitric oxide synthase activity in brain during aging," Brain Research, vol. 1216, pp. 68-77, 2008.

[10] A. Masood, Y. Huang, H. Hajjhussein et al., "Anxiolytic effects of phosphodiesterase-2 inhibitors associated with increased 
cGMP signaling," Journal of Pharmacology and Experimental Therapeutics, vol. 331, no. 2, pp. 690-699, 2009.

[11] A. S. R. Sierksma, K. Rutten, S. Sydlik et al., "Chronic phosphodiesterase type 2 inhibition improves memory in the APPswe/ PS1dE9 mouse model of Alzheimer's disease," Neuropharmacology, vol. 64, pp. 124-136, 2013.

[12] T. Podzuweit, P. Nennstiel, and A. Müller, "Isozyme selective inhibition of cGMP-stimulated cyclic nucleotide phosphodiesterases by erythro-9-(2-hydroxy-3-nonyl) adenine," Cellular Signalling, vol. 7, no. 7, pp. 733-738, 1995.

[13] J. Seybold, D. Thomas, M. Witzenrath et al., "Tumor necrosis factor- $\alpha$-dependent expression of phosphodiesterase 2: role in endothelial hyperpermeability," Blood, vol. 105, no. 9, pp. 35693576, 2005.

[14] M. Abarghaz, S. Biondi, J. Duranton, E. Limanton, C. Mondadori, and P. Wagner, "Preparation of benzo[1,4]diazepin2-one derivatives as phosphodiesterase PDE2 inhibitors," Neuro3D, Fr., Application: EP 1548011, p. 46, 2005.

[15] O. A. H. Reneerkens, K. Rutten, E. Bollen et al., "Inhibition of phoshodiesterase type 2 or type 10 reverses object memory deficits induced by scopolamine or MK-801," Behavioural Brain Research, vol. 236, no. 1, pp. 16-22, 2013.

[16] J. Pandit, M. D. Forman, K. F. Fennell, K. S. Dillman, and F. S. Menniti, "Mechanism for the allosteric regulation of phosphodiesterase 2A deduced from the X-ray structure of a near full-length construct," Proceedings of the National Academy of Sciences of the United States of America, vol. 106, no. 43, pp. 18225-18230, 2009.

[17] M. S. Plummer, J. Cornicelli, H. Roark et al., "Discovery of potent, selective, bioavailable phosphodiesterase 2 (PDE2) inhibitors active in an osteoarthritis pain model. Part I. Transformation of selective pyrazolodiazepinone phosphodiesterase 4 (PDE4) inhibitors into selective PDE2 inhibitors," Bioorganic \& Medicinal Chemistry Letters, vol. 23, no. 11, pp. 3438-3442, 2013.

[18] J. Zhu, P. Rehse, and M. He, PDE2 Catalytic Domain/PDE2Specific Inhibitor Composite Crystal and its Growth Method, American Chemical Society (ACS), Shanghai Medicilon, Shanghai, China, 2014.

[19] T. Banerjee, S. Chaudhuri, M. Moore, S. Ray, P. S. Chatterjee, and P. Roychowdhury, "Synthesis and crystal structures of 5-amino-1-(2-hydroxyethyl)imidazole-4-carboxamide and 5amino-1-(2-chloroethyl)-4-cyanoimidazole," Journal of Chemical Crystallography, vol. 29, no. 12, pp. 1281-1286, 1999.

[20] B. Alhede, F. P. Clausen, J. Juhl-Christensen, K. K. McCluskey, and H. F. Preikschat, "A simple and efficient synthesis of 9-substituted guanines. Cyclodesulfurization of 1-substituted 5-[(thiocarbamoyl)amino]imidazole-4-carboxamides under aqueous basic conditions," Journal of Organic Chemistry, vol. 56, no. 6, pp. 2139-2143, 1991.

[21] E. Shaw, "Observations on the cyclization of a substituted $\alpha$-formamidoamidine to aminoimidazolecarboxamide derivatives," Journal of Organic Chemistry, vol. 30, no. 10, pp. 33713373, 1965.

[22] U. Niewoehner, E. Bischoff, J. Huetter, E. Perzborn, and H. Schuetz, "Preparation of Purin-6-one derivatives for treatment of cardiovascular and urogenital diseases," EP 771799, Bayer AG, Leverkusen, Germany, pp.50, 1997.

[23] X. Y. Zhao, X. Chen, G.-F. Yang, and C.-G. Zhan, "Structural assignment of 6-oxy purine derivatives through computational modeling, synthesis, X-ray diffraction, and spectroscopic analysis," Journal of Physical Chemistry B, vol. 114, no. 20, pp. 69686972, 2010.

[24] J. Beltman, D. E. Becker, E. Butt et al., "Characterization of cyclic nucleotide phosphodiesterases with cyclic GMP analogs: topology of the catalytic domains," Molecular Pharmacology, vol. 47, no. 2, pp. 330-339, 1995.

[25] X.-j. Zhao, X. Chen, G.-f. Yang, and C.-g. Zhan, "Synthesis of 9-benzyl-2-substituted-purin-6-one derivatives and their bioactivity and molecular docking as potential human phosphodiesterase-2 inhibitors," Zhongguo Yaowu Huaxue Zazhi, vol. 23, pp. 277-285, 2013.

[26] R. Islam, N. Ashida, and T. Nagamatsu, "Synthesis and regioselective $\mathrm{N}$ - and O-alkylation of 3-alkyl-5-phenyl-3H-[1,2,3] triazolo[4,5-d]pyrimidin-7(6H)-ones and 2-phenyl-9-propyl$9 \mathrm{H}$-purin-6(1H)-one with evaluation of antiviral and antitumor activities," Tetrahedron, vol. 64, no. 42, pp. 9885-9894, 2008. 

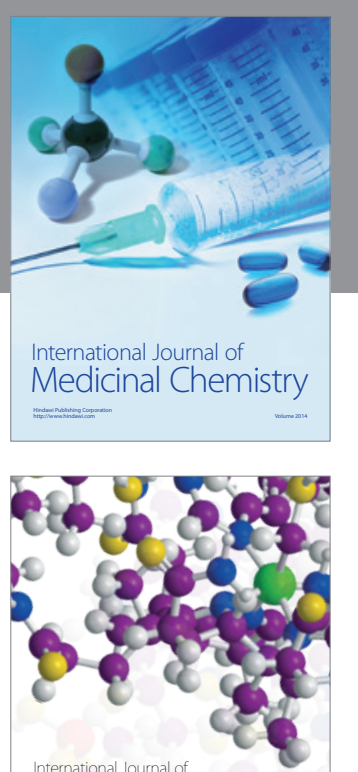

Carbohydrate Chemistry

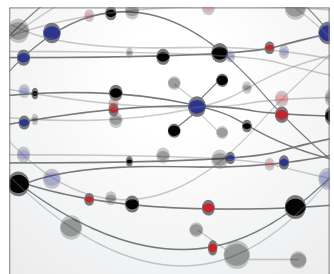

The Scientific World Journal
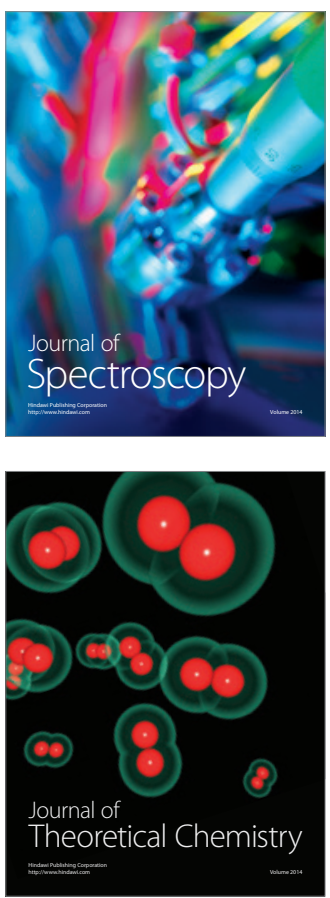
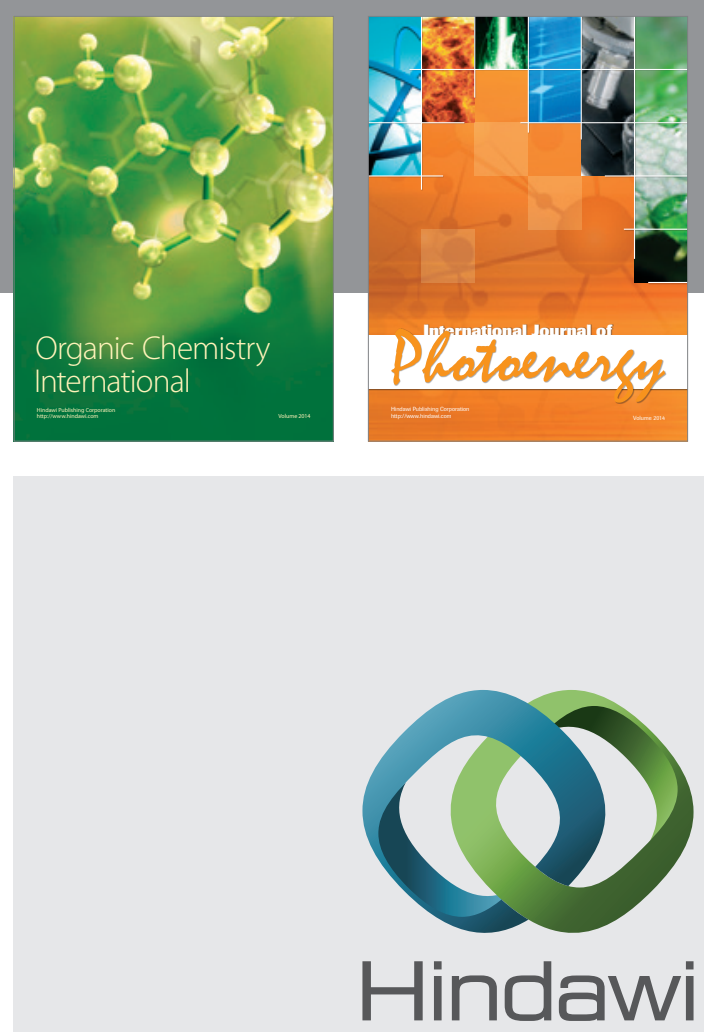

Submit your manuscripts at

http://www.hindawi.com

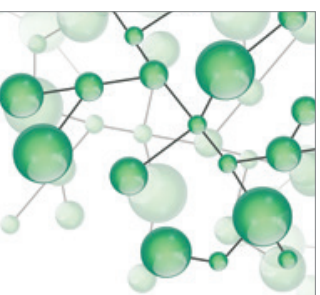

International Journal of

Inorganic Chemistry

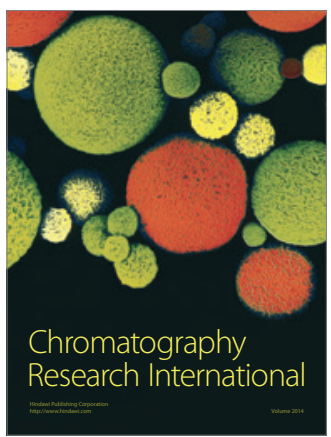

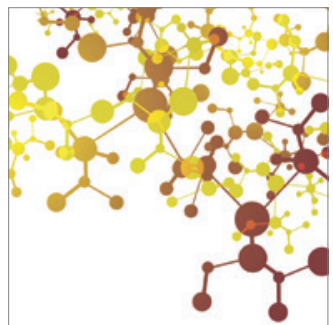

Applied Chemistry
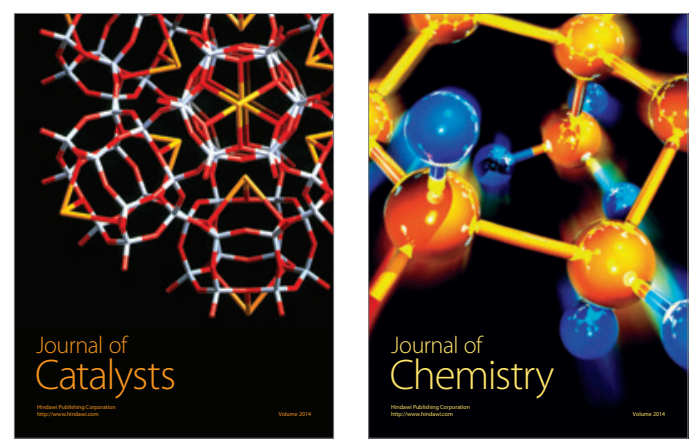
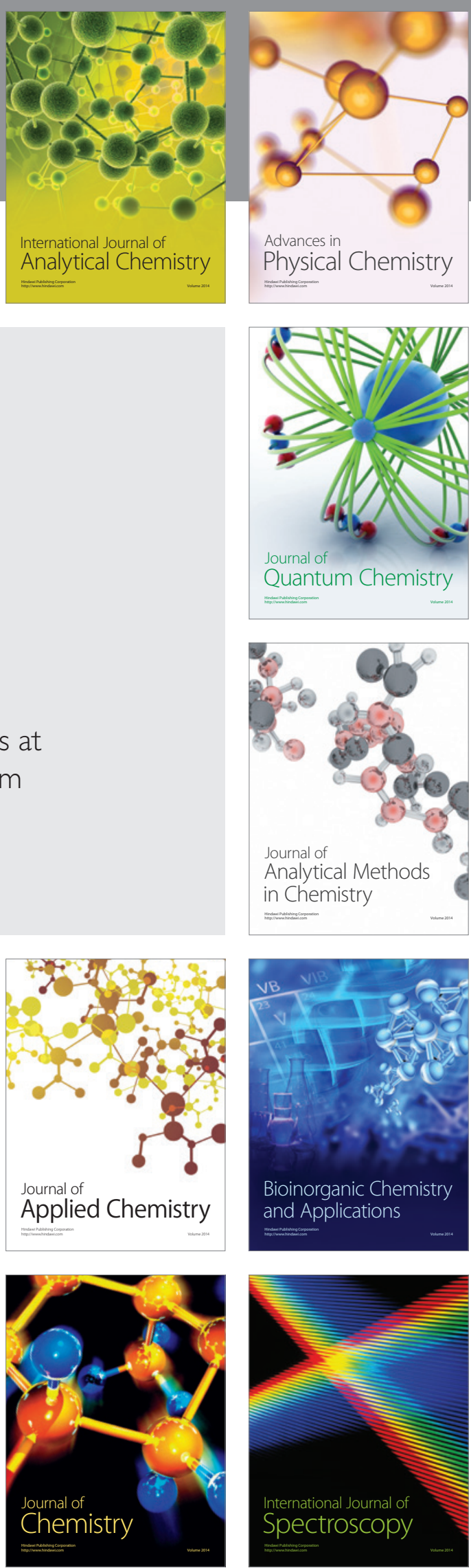